Arab World English Journal (November 2021)

DOI: https://dx.doi.org/10.24093/awej/th.279

Theses ID 279

Pp. 1-96

\title{
Adult Saudi Students' Practices and Perceptions of Utilizing Twitter for English Language Learning in the UK
}

\section{Meshari Muidh Alharthi}

King Khalid Military Academy, Riyadh, Saudi Arabia

Author: Meshari Muidh Alharthi

Thesis Title: Adult Saudi Students' Practices and Perceptions of Utilizing Twitter for English Language Learning in the UK

Institution: School of Arts and Media, The University of Salford, UK

Degree: Master of Arts in Teaching English to Speakers of Other languages and Applied

Linguistics

Major: Applied Linguistics

Year of award: 2016

Supervisor: Dr. Huw Jarvis

ORCid ID: https://orcid.org/0000-0001-9155-2131

Keywords: TESOL, Social media, Saudi students, Twitter, English language learning

\section{Abstract:}

Twitter is one of the most widely used social media platforms in Saudi populations; however, research is limited regarding the efficiency, practices, and perceptions of utilizing this platform for the purpose of learning English. This study investigates the ways in which adult Saudi students in the UK use Twitter to learn the English language, and assesses the general practices and perceptions of the social media platform. Employing a sequential explanatory research design by conducting questionnaire and interviews for data collection and analysis, this study reveals that there are several opportunities for English language learning through the use of Twitter. Participants consisted primarily of digital residents who use Twitter to practice and learn English, and many noted that Twitter contributes to refined different language skills and an enhanced vocabulary. Therefore, we strongly recommend that instructors and educators encourage students to use Twitter in an English language learning capacity wherever access is possible.

Cite as: Alharthi, M. M. (2016). Adult Saudi Students’ Practices and Perceptions of Utilizing Twitter for English Language Learning in the UK, School of Arts and Media, The University of Salford, UK (M.A.Thesis). Retrieved from Arab World English Journal (ID Number: 279) Novermber, 2021: 1- 96. DOI: https://dx.doi.org/10.24093/awej/th.279 


\section{University of Salford \\ MANCHESTER}

Adult Saudi Students' Practices and Perceptions of Utilizing Twitter for English Language Learning in the UK

A dissertation submitted in partial fulfilment of the requirements for the degree

of

Master of Arts in Teaching English to Speakers of Other languages and Applied Linguistics

at

The University of Salford, School of Arts and Media

by

Meshari Muidh Alharthi

2016 


\section{Acknowledgments}

First of all, all praises and thanks to Almighty Allah for giving me support, help, strength, knowledge, and the ability to understand and complete my MA program successfully. I am particularly grateful to my dear parents for their honest feedback and consistent prayers, as well as their positive encouragement. My sincere and warmest thanks to my beloved wife for her unconditional love and support.

I would like to express tremendous appreciation to my supervisor, Mr. Huw Jarvis, for his constant help, valuable support, continued guidance, and candid feedback throughout the process of this course and through the completion of my dissertation. My sincerest thanks and gratitude also go to the TESOL and Applied Linguistics lecturers of the School of Arts and Media at the University of Salford for their insightful comments, encouragement, and informative lectures which helped me to successfully complete the program. Special thanks to my personal tutor, Dr Siân Etherington, for her direction and advice. I also would like to thank all of my friends and classmates in this program for their continued support and contributions.

Last but not the least, my particularly warm thanks to all those who sacrificed their valuable time and offered their fullest cooperation to participate in this study. 


\section{Table of Contents}

Acknowledgments __ 2

List of Tables __ 5

List of Figures _ـ 5

List of Abbreviations ___ 6

Abstract___ 7

Chapter One: Research Introduction ___ 8

1.1 Overview__ 8

1.2 Research Background ___ 8

1.3 Research Rationale __ 10

1.4 Research Objectives and Questions 12

1.5 The Significance of Utilizing Twitter for Learning ___ 12

1.6 Summary___ 13

Chapter Two: Literature Review __ 14

2.1 Introduction 14

2.2 Theoretical Background ___ 14

2.3 The Use of Web 2.0 Tools in Education and Learning ___ 16

2.4 Mobile Assisted Language Use ___ 17

2.5 Informal Learning: Twitter as a Learning Tool ___ 18

2.6 Twitter and English Language Learning __ 20

2.7 Digital Literacy and Using Twitter in English Language Learning___ 23

Chapter Three: Methodology___ 25

3.1 Research Questions __ 25

3.2 Methodology: Research Design __ 25

3.3 First Phase: Quantitative Methods__ 27

3.4 Second Phase: Qualitative Methods _ 29

3.5 Participants__ 31

3.6 Pilot Study___ 32

3.7 Research Validity and Reliability __ 33

3.8 Ethical Consideration ___ 33

Chapter Four: Results and Analysis ___ 35

4.1 Introduction 35

4.2 Participants' Demographic Information__ 35

4.3 Use of Twitter___ 36

4.4 The Use of Twitter for English Language Learning___ 39

4.5 Informal Learning __ 43

4.6 Twitter Features _ 45

4.6.1 Multimedia __ 45 
4.6.2 Anytime and Anywhere 45

4.7 Motivation _ 46

4.8 Learners' Needs _ 47

4.9 Vocabulary _ 52

4.10 Efficiency of Using Twitter for English Language Learning ___ 53

4.11 Digital Literacy __ 55

Chapter Five: Conclusion _ـ 57

5.1 Conclusion

5.2 Further Research _ 58

References _ 60

Appendices __ 66

Appendix 1: Screenshots of Twitter Users __ 66

Appendix 2: Screenshots of different tweets __ 67

Appendix 3: Interview Transcription__ 70

Appendix 4: Consent Form

Appendix 5: Participants' Characteristics __ 78

Appendix 6: Questionnaire ___ 81

Appendix 7: Interview Questions __ 91

Appendix 8: Ethical Approval ___ 92

Appendix 9: Research Procedures___ 96 


\section{List of Tables}

Table 1: Coding system 34

Table 2: Have you ever been asked by a teacher to use Twitter outside the classroom? 46

Table 3: Reasons for using Twitter in English 48

\section{List of Figures}

Figure 1: How often do you use Twitter in a typical week? 37

Figure 2: When using Twitter, which devices do you use? 37

Figure 3: How long have you been using Twitter? 39

Figure 4: What other social networks do you use? 39

Figure 5: How often do you use Twitter in English?

Figure 6: How long have you been using Twitter for English language learning?

Figure 7: When using Twitter outside your studies, which language do you use? 42

Figure 8: When using Twitter to improve and practise your English, which language do you use?

Figure 9: When doing activities to improve and practise your English, which language do you use?

Figure 10: When using Twitter for English language learning, where do you use it? 44

Figure 11: What are your reasons for using Twitter in English? 49

Figure 12: What other social networks do you often use in English language learning? 52

Figure 13: Does Twitter help with English practice and/or learning? 55

Figure 14: Is your English language proficiency improved by Twitter? 55 


\section{List of Abbreviations}

$\begin{array}{ll}\text { PLN } & \text { Personal Learning Network } \\ \text { EFL } & \text { English as a Foreign Language } \\ \text { ESL } & \text { English as a Second Language } \\ \text { MALL } & \text { Mobile-Assisted Language Learning } \\ \text { MALU } & \text { Mobile Assisted Language Use } \\ \text { CALL } & \text { Computer Assisted Learning Language } \\ \text { OMDs } & \text { Other Mobile Devices } \\ \text { PDAs } & \text { Personal Digital Assistance } \\ \text { TESOL } & \text { Teaching English to Speakers of Other Languages }\end{array}$




\begin{abstract}
Twitter is one of the most widely used social media platforms in Saudi populations; however, research is limited regarding the efficiency, practices, and perceptions of utilizing this platform for the purpose of learning English. This study investigates the ways in which adult Saudi students in the UK use Twitter to learn the English language, and assesses the general practices and perceptions of the social media platform. Employing a sequential explanatory research design by conducting questionnaire and interviews for data collection and analysis, this study reveals that there are several opportunities for English language learning through the use of Twitter. Participants consisted primarily of digital residents who use Twitter to practice and learn English, and many noted that Twitter contributes to refined different language skills and an enhanced vocabulary. Therefore, we strongly recommend that instructors and educators encourage students to use Twitter in an English language learning capacity wherever access is possible.
\end{abstract}




\section{Chapter One: Research Introduction}

\subsection{Overview}

This paper addresses the practices and perceptions of utilizing Twitter in English language learning by adult Saudi students in the UK. Twitter offers numerous opportunities for general learning; however, research has yet to examine its particular utility in terms of learning the English language. Research questions will be answered by implementing a sequential explanatory mixed methods study (Creswell, 2009), and justification for the research will be presented in more detail in Chapter 3. Research design involved two phases, the first of which collected quantitative data through the use of questionnaire, and the second consisting of qualitative data acquired via interview. Both formats were directed towards adult Saudi students in the UK, and while the questionnaires offered an overview of the statistical findings, the interviews gave more in-depth and nuanced meaning to those results.

\subsection{Research Background}

Online learning has developed significantly in recent years, and this study analyses the ways in which social media networking platforms have contributed to that phenomenon. Specifically, the author looks at the use of Twitter by adult Saudi students in the UK for the purpose of English language learning.

Social networks, including Twitter, can be used as tools for language acquisition, a process which can now be achieved through computer and mobile devices (Jarvis \& Achilleos, 2013). Because language is socially constructed, it can be learned in a social context as learners interact and communicate in the target language (Bax, 2003). Furthermore, employing social networks likely supports 
various forms of learning in that the process is believed to occur when individuals interact without meeting face to face (Veletsianos \& Kimmons, 2013).

Online social networks have been used increasingly more by students and instructors for several purposes, including personal connection, enhanced collective input, and engaging assignments (Mazer, Murphy, \& Simonds, 2007, 2009). With respect to the use of social networks for language learning, $81 \%$ of surveyed students reported that they used a set of online tools, such as Twitter, to improve their foreign language skills (Faizi, El Afia, \& Chiheb, 2014).

Many social media activities are available to assist Twitter users in learning English. For example, well-known Twitter users such as @_Engliish_(528,000 followers), @English2Arabic (447,000 followers), and @english_as1 (23,700 followers) tweet regularly about different English language topics. (See Figures 1, 2, and 3 in Appendix 1: Screenshots of Twitter Users). These items are conveyed in standard tweets (text only), pictures, videos, or links (see figures 1, 2, 3 and 4 in Appendix 2: Screenshots of different tweets), and typically contain information regarding vocabulary and grammar or listening, reading, and writing skills. Hashtags like \#twinglish, \#learnEnglish, and \#English also enable Twitter users to connect through the platform.

This form of learning is considered subconscious language acquisition, which, according to Jarvis (2014), 'has been shown to be more powerful than conscious learning.' Subconscious language acquisition suggests that language is acquired by understanding language input through the processes of reading and listening, defined by Krashen (1982) as comprehensible input. For example, learners follow the Twitter handles of notable news networks and converse in English with strangers through the use of hashtags or direct mention concerning news stories with which they are familiar. 
This kind of social media interaction can be used to develop learners' personal learning networks (Veletsianos \& Kimmons, 2013). A personal learning network (PLN) is an informal process of education in which a learner interacts with people and derives knowledge in a personal learning environment (Utecht, 2008). Mackley (2014) defines it as a method of linking learners to a collection of different sources and people, typically via the Internet, to accomplish professional development needs. In a PLN, a learner connects and interacts with another learner or individual with the understanding that some kind of learning will occur as a result of that connection.

Generally established outside the walls of a classroom, the PLN is selfdirected, based on the learner's interests and needs, and is normally controlled by the learner (Marsick \& Watkins, 1990). Applied to social media platforms, online interaction could help learners to develop their skills and improve their language through informal PLNs (Hockly \& Dudeney, 2013).

Nevertheless, the use of social networks as virtual learning environments can lead to several challenges and issues. Jarvis (2014) highlights digital literacy and footprints two such concerns in the TESOL field.

\subsection{Research Rationale}

New media, particularly the Internet, have become one of the most prevalent vehicles for communication and information in recent years, accompanying a rapid increase in the number of Internet users (De Waal \& Schoenbach, 2010). According to Internet World Stats (2012), more than 2 billion people across the globe consider themselves to be Internet users; therefore, Twitter offers universality, as well as the opportunity to be used for different purposes including language acquisition.

Social media has traditionally played a number of different roles in society, 
having been used in a number of different fields, such as economics, politics, and education. It has become one of the most valuable tools for education, enabling its users to interact freely with their peers, teachers, and external sources to discuss certain educational topics or to learn new subjects. The most popular of the social media platforms now is Twitter, which will be the platform examined in this paper.

Twitter has gained enormous popularity among Internet users as a useful tool for a number of purposes, such as communication, business, and education. This popularity stems from its availability and ease of access, most notably the fact that it is free to users, as well as the fact that no specific skill set or knowledge is needed to operate it. According to Twitter (2015), the financial results of Third Quarter 2015 reported 320 million average monthly active users, a contrast from the previous quarter, which revealed 316 million monthly active users.

It is worth noting that among those users, approximately $80 \%$ accessed the platform from mobile devices (Twitter, 2015), and more than 4.8 million did so from Saudi Arabia, which, according to PeerReach (2015), represents the highest number in the Arab region. Saudi Arabia is considered the world's fastest-growing Twitter nation (Fraij, 2015), a fact which provides validation for conducting the present study.

Remarkably, although initially targeting youths and teenagers, social media has found its place among older populations, where roughly $82 \%$ of Internet users are between 30-49 years old and 65\% of social media users are between 50-64 years old, percentages that have increased by approximately $14 \%$ and $15 \%$, respectively, since August 2011 (Pew Research Centre, 2014). The growing interest in and reach of social networks within every age bracket indicates the opportunities for researchers, educators, and especially learners to capitalize on social networking platforms in the pursuit of various educational objectives (Veletsianos, 2011). 
For the purpose of contributing to the extant literature and knowledge base, this study will focus on the learning opportunities for users from the Middle East, specifically those from Saudi Arabia. No research to date has specifically examined the use of social media by adult Saudi students in the UK for the purpose of learning English. The present study will address this dynamic by answering the research questions listed below, taking into account the following objectives:

\subsection{Research Objectives and Questions}

\section{-Research Objectives:}

- Identify the effectiveness of Twitter in English language learning for adult Saudi students in the UK

- Identify specific practices employed by adult Saudi students on Twitter for English language learning

- Explore adult Saudi language learners' perceptions regarding the use of Twitter for English language learning

\section{-Research Questions:}

- To what extent do adult Saudi students in the UK believe their language learning is enhanced by the use of Twitter?

- How do adult Saudi students in the UK use Twitter to learn the English language?

- What are the perceptions of adult Saudi learners in the UK regarding the use of Twitter to learn English?

\subsection{The Significance of Utilizing Twitter for Learning}

One of the most significant and widely-used aspects of the Internet is social media technology. Conley, Lull, and Monsalve (2010) define social networking sites as 'a means of communication between individuals which facilitates exchanging, sharing, and editing information through modern technology' (p. 70). Social media platforms such as Twitter have become an intrinsic part of daily life (Tess, 2013) and 
have had a significant impact on societies all over the world, playing a pivotal role in a number of fields like education and language acquisition. By conducting this exploratory study, the author expects to contribute to the extant research and provide insight into how Twitter is used and perceived by adult Saudi students in the UK.

\subsection{Summary}

The objective of this study is to explore the potential role that Twitter can play in students' acquisition of the English language. As discussed above, social media has become a major source of connectivity and communication throughout the world, and the present study focuses on the effectiveness of Twitter for English language learning by adult Saudi students in the UK. 


\section{Chapter Two: \\ Literature Review}

\subsection{Introduction}

Scant research exists regarding the possibility of using Twitter in English as a foreign language (EFL) or English as a second language (ESL) learning; however, this chapter will incorporate peer-reviewed literature surrounding Twitter and microblogging to establish how Twitter might be adopted for English language acquisition. Due to its universal availability and its interactive functions, Twitter can serve as a suitable environment for simplifying the process of learning English. By adopting Twitter, learners have access to both native English speakers as well as opportunities to observe and engage with English vocabulary and grammar in a practical and conversational atmosphere

The chapter will also discuss how the use of technology to improve learning efficiency is useful when the content and the structure of a course are well-blended and well-organized, a fact which has been studied and proven, according to Lee and Rha (2009). In addition, the chapter will highlight the ways in which Twitter can facilitate a PLN when users engaged in conversation with people whom they only know online (Belshaw, 2007).

\subsection{Theoretical Background}

Affirming that learning occurs in virtue of a learner's experience and interaction with the content or other people, Driscoll (2000) defines learning as 'a persisting change in human performance or performance potential' (p.11). Language education theory has shifted towards social constructivism, which arose from Vygotsky's 1978 work proposing that learning happens via interaction negotiation (Jarvis, 2013; Vygotsky, 
1978). According to Bax (2003), learning is socially constructed; therefore, a social network like Twitter could be used as a medium to learn or practice language, either consciously or unconsciously, through computers and mobile devices (Jarvis \& Achilleos, 2013). Moreover, language can be learned in a social context, as learners interact and communicate in the target language. Through the emergence of mobile devices, Internet users are now more likely to be digital residents, and the majority of those users are non-native English speakers (Jarvis, 2014). According to White and Cornu (2011), a digital resident is a user who spends a considerable amount of time online and, normally, uses different apps or programs on mobile devices, including tablets and smartphones.

Regarding the concept of cooperative learning, social interaction is the prime principle behind the cyber learning environment, whereby stronger learners assist weaker ones with mutual learning objectives in well-organized environments (Tsai et al., 2008). In Kolb's Experiential Learning Theory, social learners are seen as leaders. They learn better when they tackle a problem as a group, and they rely on their own intuition and information from peers and other people rather than from lessons and course books (Kolb, 2014).

Social interaction in the target language has many benefits (Lu \& Yeh, 2008), two of which are the significant exposure users receive in terms of the target language itself, as well as the opportunity to practice delivering their thoughts concisely and in organized syntactic structures through tweets, which are limited to 140 characters on Twitter (Borau et al., 2009). Communicative competence is therefore supported and enhanced through social interaction when users read and write, and otherwise engage, in the Twitter environment (Borau et al., 2009).

Many educators believe that linguistic competence can be reinforced and 
individual social engagement can be enhanced by adopting information technology as a tool. This happens in global communication in which there are no geographic restrictions (Cummins, 2000). Learners' cognitive development is facilitated by the process of social interaction when stronger learners inspire their weaker peers. This socialization process using communication activities is highly significant, as it leads to language internalization (Vygotsky, 1985); therefore, learners' interaction and engagement are enhanced when technology is used in language leaning (Yang, 2011).

The most important benefit of applying Twitter to English language acquisition is the increase in opportunities for interaction (Dunlap \& Lowenthal, 2009). Underscoring the appeal of the application's timeliness and brevity, Dunlap and Lowenthal (2009) note that students' learning engagement is increased by the use of Twitter, and the authors suggest that collaborative learning might be enhanced as information is quickly exchanged.

In addition to increased social interaction, Twitter offers the anonymity often necessary for open dialogue and, therefore, learning. Reserved and introverted learners may feel more comfortable producing and contributing ideas in an environment in which they are somewhat removed from the process of delivering those ideas themselves (Young, 2010). The adoption of Twitter as a language acquisition tool has the potential to encourage and motivate English language learners, as well as increase the chance of interaction inside and outside of the classroom.

\subsection{The Use of Web 2.0 Tools in Education and Learning}

Nowadays, people prefer to express their feelings and views on certain topics, as well as connect with others, through the use of blogging, messaging, and posting photographs and videos. Typically used by individuals to interact and communicate 
promptly and concisely, Twitter is a microblogging service in which information is exchanged quickly between different social entities. Social media platforms such as Twitter are classified as Web 2.0, which involve sites that focus on user-generated content, as well as flexibility, usability, and universality. Web 2.0 has redefined the notion of online learning. It is identified as a personal learning environment (PLE). whose values are mainly concerned with enhancing social networks and communication, as well as emphasizing the production of decentralized content (Downes, 2007).

The benefit of using social networking and its applications in English language learning stems from the interaction between learners when they develop shared understanding and address difficulties in their studies (Madge et al., 2009; Selwyn, 2009). On this basis, Web 2.0 technologies allow users to produce and exchange content, as these platforms are based on the concept of collaboration and interaction. These platforms have a significant impact on people's personal and professional lives; but most importantly, they have a substantial influence on the way people learn.

\subsection{Mobile Assisted Language Use}

In addition to social media platforms, mobile-assisted language learning (MALL) and Mobile Assisted Language Use (MALU) (Jarvis and Achilleos, 2013) play a role in the ability of individuals to engage and learn through technology. The rapid growth and significant change in communications technology has resulted in a shift from Computer Assisted Learning Language (CALL) to MALL. Livingstone (2012) referred to Computer Assisted Language Learning (CALL) as the use of computer programs and application to ease the processes of language teaching and learning. 
As is mentioned in this definition, a computer is typically involved in the CALL process of improving the learner's language; however, Other Mobile Devices (OMDs) have recently received widespread recognition, as well. OMDs can be smartphones, iPods, tablet PCs, MP3 players, and PDAs. Whereas CALL is limited to computer use, MALL can be applied to all OMDs, thereby enhancing the availability, utility, and access of learning via various platforms, and ultimately facilitating language learning (Trifanova et al, 2004).

Although MALL and CALL are both considered ways of assisted language learning, the emergence of MALL has encouraged more informal learning outside of the classroom through the use of mobile devices (Murray \& Hourigan, 2006). Introduced by Jarvis and Achilleos (2013), MALU comprises more than desktop and even laptop computers, and emphasizes that more than mere language instruction and/or learning can be attained through technology. MALU constitutes all CALL and MALL features, including conscious learning via desktop, laptop, and OMDs, as well as the recognition of social uses in the target language in different learning situations whether it is formal or informal learning (Jarvis and Achilleos, 2013).

\subsection{Informal Learning: Twitter as a Learning Tool}

One of the most significant trends in learning nowadays is informal acquisition, stemming from the fact that the majority of our learning does not come about from formal learning anymore, but rather from multiple avenues such as personal networks and work-related tasks (Siemens, 2005). Learning is no longer only about know-how and know-what; it is also about know-where, or the notion of where to find information we need, where competence is derived from forming connections.

Informal learning usually takes place outside of a classroom. It is self-directed 
and based on the learner's interests and needs and is normally controlled by the learner (Marsick \& Watkins, 1990). Informal learning plays a significant role in our learning experience. Formal education no longer represents the majority of our learning; rather, learning now occurs in a variety of ways, through communities of practice, personal networks, and through the completion of work-related tasks. Jarvis (2014) found that a high number of students participating in his study used English through social media as a means to an end, indicating that they were not consciously practicing vocabulary or grammar, although they might absorb it as a side effect of their interactions (Jarvis, 2014).

Shared interests and needs can be improved and developed by providing a platform where individuals can discuss hobbies on an equal plane. A Twitter hashtag might, for example, be a place of informal learning, in which learners informally converse in English about their common interests, such as a football team. In order to contribute to the English dialogue, they might incorporate the hashtag to express their opinions about a recent football match to others in English. This comprehensive online interaction through social media can help learners to develop their listening, reading, writing, and speaking skills and improve their grasp of the language (Faizi, Afia, and Chiheb, 2014; Hockly \& Dudeney, 2013).

Social networks have been seen as tools for creating, exchanging, and sharing knowledge by the e-learning community (Grosseck \& Holotescu, 2008; Huberman et al., 2008). In particular, microblogging platforms are a novel form of communication that can support informal learning beyond the classroom environment (Ebner et al., 2010), suggesting that learners' informal learning activities can be bolstered by adopting a social network such as Twitter (Aspden \& Thorpe, 2009). Twitter is a useful learning tool in that it fosters intrinsic understanding and facilitates real-life 
learning connections by encouraging critical reflection (Bonwell \& Eison, 1991; Cherney, 2008).

In a study conducted by the National School Board Association (2007), it was found that nearly $60 \%$ of participants used social media to discuss and debate education topics. This and similar studies have motivated educational policymakers to consider the learning opportunities offered by social media in formal and informal learning (Bull et al., 2008).

\subsection{Twitter and English Language Learning}

Providing message boards, personal blogs, photo albums, and video galleries, social media platforms are now widely used by people who enjoy connecting with others and expressing their opinions and views on current events and topics of interest. The world's fastest-growing social media platform, Twitter was launched in July 2006 as a microblogging platform which enabled users to exchange information quickly and across various social groups. Since its creation, however, it has been used not only as a social networking tool, but also for more serious and formal purposes, such as issuing court injunctions.

People around the world use Twitter to raise their voices and overcome the power of political tyranny. They are more engaged in direct conversation and can express their opinions to an unlimited audience, including institutions and people. Some of the earliest tools that have seen an increase in use are message boards, chat rooms, blogs, and emails (Levy, 2009). These tools have offered language learners a number of opportunities to help them participate actively through various channels of communication. 
One such tool, as previously mentioned, is microblogging, which has achieved enormous popularity since the introduction of its most notable program, Twitter. Characterized by its simplicity and reliance on mobile devices, microblogging requires little to read and write messages, and has therefore attracted a number of Internet users as a result of its practicability, availability, and simplicity (Holotescu \& Grosseck, 2011). What makes Twitter ideally suited for second language learners is that a tweet is limited to 140 characters, which is about two to three sentences. Therefore, learners can read and write tweets easily (Luo \& Gao, 2012).

Educators quickly recognized the potential implications of the Twitter platform in education, and Educause (2007) suggested that Twitter might be used to foster interaction and effective communication in an educational setting. In 2008, Twitter was identified as being particularly appropriate for language learning (Dickens, 2008), and by 2009, experts were identifying and presenting the important uses of Twitter at e-learning conferences worldwide (Wheeler, 2009).

The standard Twitter experience consists of brief and instantaneous interactions. Twitter posts are called tweets and, as referred to earlier, are limited to 140 characters, including spaces and punctuation. This limitation requires users to possess and exhibit highly detailed language accuracy and communicative precision (Grosseck \& Holotescu, 2008). Users can follow each other and reply to tweets in continual daily conversations, about which tropics range from politics to sports and education. Users who are not willing to express themselves in public can use Twitter as a medium to communicate anonymously. In addition, Twitter can be used as a profile for users such as celebrities, organizations, institutions, and companies to share their personal thoughts and to promote their products on a virtual platform. 
Real-time interaction between users is the key characteristic of microblogging, an asset which can be achieved using different devices, technologies, and applications. Twitter, Tumblr, Pownce, and Jaiku, the best-known microblogging services, have the potential to offer English language learners numerous potential benefits. A large number of language educators have already successfully integrated various online communicative tools into their educational repertoire (Garrett, 2009; Levy, 2009; Meskill \& Anthony, 2010), and online interaction through social media has been found to help learners refine their language skills and improve their language (Hockly \& Dudeney, 2013).

Users typically adopt Twitter for asynchronous interaction (Dunlap \& Lowenthal, 2009; Grosseck \& Holotescu, 2008), and when compared with other regular blogs, the microblogging features of Twitter are focused mainly on the higher frequency of personal updates, as well as the rapid spreading of information. In addition, Twitter can, as a platform for fast communication, play a role as a stimulus for language learning in which target language communicative ability is potentially improved (Borau et al., 2009). The limitation of 140 character is seen as a useful language learning tool (Dickens, 2008); however, this feature is also blamed by some educators for playing a part in declining English writing skills (Kelley, 2010). Nevertheless, Parry (2008) argues that it can be used to develop the same skills as learners would have to condense their thoughts into two short sentences, thereby requiring them to use the precise words needed to convey their idea or opinion.

The emergence of new media, particularly the Internet, has become one of the most prevalent vehicles for communication and information, accompanying a rapid increase in the number of Internet users (De Waal \& Schoenbach, 2010). Of more than two billion Internet users (Internet World Stats, 2012), roughly 289 million of them 
are active Twitter users, according to Statistic Brain (2015), placing Twitter in the top ten most popular Internet sites (Alexa, 2015).

\subsection{Digital Literacy and Using Twitter in English Language Learning}

Due to the rapidly evolving nature of Web 2.0 technology, the use of Twitter for language acquisition purposes does not necessarily guarantee its proper or effective use. Learners must not only keep up with their language skills, but also with constant technological advances and user requirements; therefore, Jarvis (2014) suggests that developing digital literacy skills in TESOL should be the main concern of educators.

Digital literacy has been defined by Dudeney et al. (2013) as 'the individual and social skills needed to effectively interpret, manage, share, and create meaning in the growing range of digital communication channels' (p. 2). Jarvis (2014) provides a more relevant definition, calling digital literacy 'the skills needed to operate efficiently, effectively, and appropriately in an online environment in English as an L2.' Digital literacy skills are not only necessary for accessing and using technology, but also engaging in online conversations as an active and fair participant (Jarvis, 2014).

Moreover, digital literacy involves the ability to evaluate the quality of the content that is available online, which is known as information literacy. Dudeney et al. (2013, p.2) define information literacy as 'the ability to critically identify, evaluate, locate, and analyze information on the Internet and social networks that can be credibly and effectively used'. Learners should therefore hone their skills in regards to knowing the difference between '.com' and '.edu', avoiding plagiarism, and understanding how to reference literature in an ethical manner. By mastering digital 
and informational literacy skills, learners will be able to not only adopt Twitter, but also refine their grasp of the English language while keeping up with most current technology and platform updates. 


\section{Chapter Three: \\ Methodology}

\subsection{Research Questions}

According to Creswell (2009), research questions in mixed methods research can be written in many different ways. He affirms that 'both quantitative and qualitative questions can be advanced at the beginning or when they emerge during a later phase of the research' (Creswell, 2009, p.138).

Two phases were introduced in this study: the first phase involved quantitative questions, followed by the second phase, which explored qualitative aspects. By using this method, the importance of both qualitative and quantitative studies was emphasized by their combined strength (Creswell, 2009).

Both phases attempted to answer the following questions:

- To what extent do adult Saudi students in the UK believe their language learning is enhanced by the use of Twitter?

- How do adult Saudi students in the UK use Twitter to learn the English language?

- What are the perceptions of adult Saudi learners in the UK regarding the use of Twitter to learn English?

\subsection{Methodology: Research Design}

The researcher employed a mixed methods design for this study. Mixed methods design is defined by Johnson and Onwuegbuzie (2004) as a kind of research in which quantitative and qualitative methods, techniques, concepts and approaches are mixed or combined by the researcher in one single study. Choosing mixed methods for a piece of research will help the researcher to answer his or her questions using different approaches instead of being limited to one. Furthermore, in order to stand a greater chance of gaining useful data, research methods should follow the research 
questions (Johnson \& Onwuegbuzie, 2004).

Benefits of the mixed methods approach include consideration of multiple perspectives (Johnson \& Onwuegbuzie, 2004) and the ability to better address validity and reliability issues due to combined data (Dörnyei, 2007). To ensure validity, this study employs method triangulation, which is defined as a combination of multiple data sources and methodologies that reduces research bias (Denzil, 1987; Dörnyei, 2007; Johnson, 1992; Mackey \& Gass, 2005).

The present study follows mixed method design (Creswell, 2009), namely, sequential explanatory design. Sequential explanatory design is defined by Creswell (2009) as research that is conducted in two phases, whereby quantitative data are collected and analysed in the first phase, followed by a second phase, based on the results of the first, in which qualitative data are collected and analysed (Creswell, 2009). Quantitative data were used to set the scene for this study. By conducting a questionnaire, the researcher was able to gain an overarching view of the situation, which would then set the tone for the interviews. The quantitative and qualitative data are integrated for better presentation and analysis in the results and discussions chapter.

In the first phase, quantitative numeric data were obtained by sending out an online questionnaire on Twitter. The questionnaire was followed by in-depth, semistructured interviews with three individuals in an effort to gather qualitative data from the interview transcriptions. By obtaining quantitative and qualitative data through the use of mixed methods, the researcher can more fully understand the practices and perceptions of Saudi students when they use Twitter to learn English. The quantitative method provided statistical results regarding the degree to which Twitter was used in English language acquisition by Saudi students in the UK; however, since the main 
objective of this study is to determine the perceptions and practices of the students, a qualitative method offered the researcher the opportunity to investigate and explore the nuances of these factors (Denzin \& Lincoln, 1994).

A naturalistic approach, normally accomplished by deriving findings 'from the real-world settings where the phenomenon of interest unfolds naturally,' is used by qualitative researchers when pursuing questions of this nature (Patton, 2002, p.93). The first-hand perspective of the participant is obtained by conducting semistructured, in-depth interviews, which provide more detailed insight into individuals' opinions about the topic in question (Oppenheim, 2001).

Overall, a complete and contextual picture of the study components can be derived by employing mixed method (Jick, 1979). Quantitative data give an initial and general idea of the degree to which Twitter is used in English language learning, as well as its effectiveness, while qualitative data help to illustrate the results through investigating the participants' views more deeply.

\subsection{First Phase: Quantitative Methods}

The quantitative tool used for collecting data in this phase was a questionnaire. Questionnaires can be defined as written instruments which present participants with a set of statements and questions to which they respond by writing their answers or choosing them from a range of given responses (Brown, 2001). There are two types of questionnaire questions: closed-ended and open-ended (Mackey \& Gass, 2005). For the purposes of this study, closed-ended items were used, with predetermined answer choices crafted by the research, because closed-ended questions are more easily quantified (Mackey \& Gass, 2005). 
Questionnaires were selected as a research tool because they are more economical and practical than individual interviews. They also save time as they elicit the information needed in a short period of time, which made them appropriate for this project as it needed to be completed in a short window of time. In addition, a questionnaire can be sent and administered in various ways, such as through email, by telephone, in person, and through social media; therefore, for the purpose of this study, and as it concerned Twitter, the questionnaire was administered via Twitter, offering the researcher considerable flexibility in the process of data gathering (and incidentally highlighting yet another benefit of the social media platform) (Mackey \& Gass, 2005).

The researcher attempted to achieve a simple and uncluttered format in the questionnaire, as well as unambiguous and answerable questions, in order to maximize the effectiveness of the instrument. The questionnaire was then reviewed by colleagues and several researchers. Opting for closed-ended questions with predetermined answer choices was intended to enhance the reliability of the quantitative data since closed-ended questions usually involve a greater uniformity of measurement (Mackey \& Gass, 2005).

The researcher decided not to use a questionnaire with open-ended items because the participants might not have felt comfortable when expressing themselves in writing. This could have led participants to provide abbreviated responses instead of elaborative ones (Mackey \& Gass, 2005). During the qualitative portion of the study, the researcher used semi-structured interviews for the same reason: to reduce the potential discomfort of participants.

Dörnyei and Taguchi (2009) note that the item format should be taken into account when organizing a questionnaire. This means that when a questionnaire 
involves items of various types, they should be clustered together into sub-sections with clear instructions, which makes answering questions smoother and easier (Dörnyei \& Taguchi, 2009). For this reason, the questionnaire was divided into three key parts: The first part was concerned with obtaining information about Saudi students' Twitter membership and usage; the second part gathered information about the participants' perceptions and practices when using Twitter for English language learning purposes; and the last part collected basic demographic data, such as the students' name, age, gender, and institution. The rationale for putting demographic questions at the end of questionnaire was that it might be boring and anticlimactic if they were placed at the beginning (Dörnyei \& Taguchi, 2009). By leaving the personal questions until the end, the researcher hoped to maintain participants' enthusiasm while responding. (See Appendix 6: Questionnaire)

\subsection{Second Phase: Qualitative Methods}

This research is founded upon the idea that reality is multiple, which means there are multiple perspectives of truth (Denzin \& Lincoln, 2003). Reality is also constantly changing through the interpretations of research participants and researchers; therefore, reality is socially constructed. Truths, then, are value-laden and regarded as a subjective reality by their very nature because individuals experience them differently.

The main focus of the second, qualitative phase was to explain the results of the first, quantitative phase and then to delve deeper into the participants' perspectives and perceptions about the questions they had been asked; therefore, in-depth interviews were used in this phase. Kern (2006) notes the significance of 'understanding the effectiveness of technology in terms of the specifics of what people 
do with computers, how they do it, and what it means to them' (p.189). Presenting the voices of the learners is very important, particularly in this study, as it contributes to our understanding of how Twitter is used by the learners themselves, and how effective it might be.

In-depth interviews were decidedly more suitable for collecting qualitative data in this study, as the research was concerned with learners' perceptions and practices. Mackey and Gass $(2005$, p.173) state that 'Interviews can allow the researcher to investigate phenomena that are not directly observable, such as learners' self-reported perceptions or attitudes'. Interviewing participants is not simply about 'getting the facts,' but also involves seeking understanding; therefore, the researcher must establish a relationship with participants, as that allows for the open emission of ideas and enables respondents to share their perceptions of the world through 'professional conversations' (Kvale, 1996, p.5).

By conducting interviews, participants have the opportunity to say what they want and to say as much as they like; therefore, the role of the researcher is reduced to a minimum so as to prevent bias. Additionally, the researcher should avoid interviewing participants he or she knows or 'leading' interviewees to answer in a particular way. Semi-structured interviews employ a list of written questions that help the researcher as a guide, although he or she can digress and engage further in order to obtain more information if desired (Mackey \& Gass, 2005). The researcher can also ask participants to clarify answers that are vague, off-topic, or incomplete.

My focus as a researcher was on the themes and questions that I had determined would be discussed; however, participants had the freedom to express their feelings and opinions and discuss what they wished, as well. As a result, new topics and subsequent research questions could be uncovered and tangents could be explored. 
The interviewer is seen here as a 'miner' or 'traveller,' whereby he or she mines for valuable information and discovers new aspects of the original research question (Kvale, 1996, p.3-4).

\subsection{Participants}

This study was directed towards adult Saudi students who live and study in the UK. This choice was made for two reasons: First, Saudi Arabia has the highest number of Twitter users in the Arab region, with more than 4.8 million active users (PeerReach, 2015), which accounts for over $40 \%$ of all active users in the Arab region; and second, the teaching context in the researcher's home country is concerned with Saudi students, where the findings of this study might be useful and could ultimately be applied.

Participants were mostly full-time undergraduate or postgraduate students studying different subjects and courses at various universities throughout the UK, and were classified as learning English as a second language (ESL). The researcher aimed to have approximately100 adult Saudi students participate in the questionnaire, and interviews were held in Arabic to avoid any communication issues, as the students' level of English proficiency might have been too low to contribute a detailed perspective or encourage confidence in responses (Mackey \& Gass, 2005). An indicative example of interview transcriptions are provided in the appendices (See Appendix 3: Interview Transcription), and more details about participants are provided in Chapter 5, 'Results and Analysis: Participants' Characteristics'.

Participants included 206 individuals who completed the online questionnaire, which was sent out as a link via Twitter. Due to incomplete answers, 94 questionnaires were discarded, leaving only 112 questionnaires fully completed. Participants were all 
adult Saudi students living in the UK, whose native tongue was a language other than English.

\subsection{Pilot Study}

Prior to distributing the questionnaire, it is essential to run a pilot study, otherwise known as field testing, because data and response accuracy depends on the accurate phrasing of questions and statements. A pilot study is observing the questionnaire at different phases of its development, and it is typically performed on a sample population which corresponds to the demographics of the target sample for which the questionnaire has been designed (Dörnyei, 2003). Running a field test allows the researcher to obtain feedback on the designed instrument, assess its weaknesses, and indicate whether it is likely to perform its designated objective. Based on the information acquired, the researcher will have the opportunity to make alterations and changes prior to distributing the final version of the questionnaire. By conducting a pilot study, the credibility of the research and validity of the questionnaire are enhanced (Cohen, Manion, \& Morrison, 2007).

In this study, the researcher conducted a pilot study before he distributed the questionnaire to the participants. The field test questionnaire was distributed to ten adult Saudi students in the UK to confirm that there was no ambiguity or difficulty in the format, and that all questions and statements were easy and clear. Students provided feedback, and the questionnaire was modified and improved as a result. Some questions were altered and others were deleted, and the final version was approved by the supervisor before it was administered to the target sample. 


\subsection{Research Validity and Reliability}

An important reason for the use of a combined quantitative and qualitative method is to enhance validity and reliability. One of the key limitations of qualitative research is the size of the sample, which is small and typically difficult to generalize to larger, more diverse populations. This limitation can be avoided by incorporating a quantitative method, as it involves a larger number of participants and is less subjective than an interview. To confirm reliability, the study is replicated and the same or similar results should emerge when conducting each iteration of a quantitative research tool. The same cannot be expected of qualitative studies, which are based on individuals' lives and perspectives in very specific contexts.

In Appendix 9, the researcher has provided a model of the procedures undertaken in this study, which shows a sequential explanatory mixed methods design. The researcher's main priority was obtaining qualitative data from in-depth explanations of participants, as the analysis focuses on identifying and understanding the perceptions and practices of Saudi students with regard to using Twitter in a language learning capacity. The rationale for starting the sequence with the quantitative phase was to capture a general portrait of how Saudi students use Twitter, after which participants were selected for interviews and further questions were derived from the questionnaire results. The results from both portions of the study were then merged, and conclusions were based on the integrated findings.

\subsection{Ethical Consideration}

Ethical issues must be addressed when conducting research into the social silences, and specifically education, as studies will likely face ethical challenges as a result of human involvement (Dörnyei, 2007). Ethical issues might include hurting the 
participants mentally or physically, or posing any threat towards them in a way that could negatively affect either the individual or the results of the study (Mackey \& Gass, 2005). Ethical issues are more prevalent in qualitative studies, as the researcher is closer to the interviewee's private life and the participant is likely to divulge his or her personal opinions, feelings, and beliefs (Dörnyei, 2007). Each of these issues was considered at the early stages of the study, as well as throughout the process.

Sensitive topics and questions related to individuals under the age of 18 were excluded from the research tools. Informed consent was provided by all participants in both the questionnaire and interview phases (See Appendix 4: Consent Form), and names of the participants were not mentioned in this study, although initials were used in the following coding system.

Table 1: Coding system

\begin{tabular}{|l|l|l|l|}
\hline City & Gender & Initial & Coding \\
\hline Manchester & Male & H & MMH \\
\hline Manchester & Male & I & MMI \\
\hline Birmingham & Female & N & BFN \\
\hline
\end{tabular}




\section{Chapter Four: \\ Results and Analysis}

\subsection{Introduction}

This study was conducted to find reasonable answers for the following questions: To what extent do adult Saudi students in the UK believe their English language learning is enhanced by the use of Twitter? How do adult Saudi students in the UK use Twitter to learn English? What are the perceptions of adult Saudi learners in the UK regarding the use of Twitter for English language acquisition? The quantitative and qualitative data obtained from the questionnaire and the interviews, along with the results from those processes, are integrated and discussed under the following subheadings.

\subsection{Participants' Demographic Information}

With regard to gender, 76 of the 112 participants were male, constituting $67.9 \%$ of the sample. The remaining 36 participants were female, making up the other $32.1 \%$ of the sample. The lower number of female participants is suggestive of usage patterns, illustrating the higher likelihood of Twitter engagement from males, who account for 55.5\% of Saudi Twitter users, according to Fraij (2015). (See Appendix 5: Figure 1).

In terms of age, Figure 2 shows that the largest percentage of Twitter users are those between the ages of 28 and 37 years, an age group that constitutes $56.3 \%$ of the participants. This group is followed by those between the ages of 18 and 27 years, which makes up $23.2 \%$ of the participants. The smallest group age falls between 38 and 47 years, and the sample included no participants over the age of 48 years. (See Appendix 5: Figure 2). 
With respect to the types of courses and programs in which participants were enrolled, 54.5\% of the were studying different English language courses, whereas the $45.5 \%$ were involved in other undergraduate and postgraduate programs. (See Figure 3). The number of students who are not enrolled in any English language courses accounts for $42 \%$ of participants, or 47 individuals. On the other hand, $40.2 \%$ of the participants were studying at the university language centre, and only $17.9 \%$ went to a private school for lessons in English. (See Appendix 5: Figure 4). Participants were also studying in various English schools and educational institutes. The chart is divided into three parts: university language centre, private school of English, and other (e.g. pursuing degrees, higher studies, or none of these).

As this study is directed at adult Saudi students who live in the UK, participants were all non-native speakers of English who are learning or using English consciously or unconsciously. In other word, they are enrolled in different courses, each requiring English proficiency. In response to the question, 'For what purpose are studying this course?,' the vast majority of participants (79.5\%) answered with 'University studies' (e.g. Bachelor degree, Master, or PhD), where high levels of English proficiency are required, while $20.5 \%$ responded that they explicitly wished to improve their English proficiency. (See Appendix 5: Figure 5).

\subsection{Use of Twitter}

This section of the questionnaire deals with participants' use of Twitter, and results show that the majority of participants are digital residents who use Twitter frequently, nearly all through the use of mobile devices. As presented in Figure 1 , below, more than $75.9 \%$ (85) of participants use Twitter five times or more each week, while $14.3 \%$ (16) use the platform two to four times and $9.8 \%$ (11) use it once a week 
or less. Participants appear to be continuously connected to Twitter via mobile devices, which is exhibited in the results of the question, 'When using Twitter, which devices do you use?' (See Figure 2). An impressive number (110, or 98.2\%) of participants use mobile devices to access their Twitter accounts, indicating the existence of numerous digital residents, who are classified by their use of mobile devices and their inclination towards constant online contact and engagement.

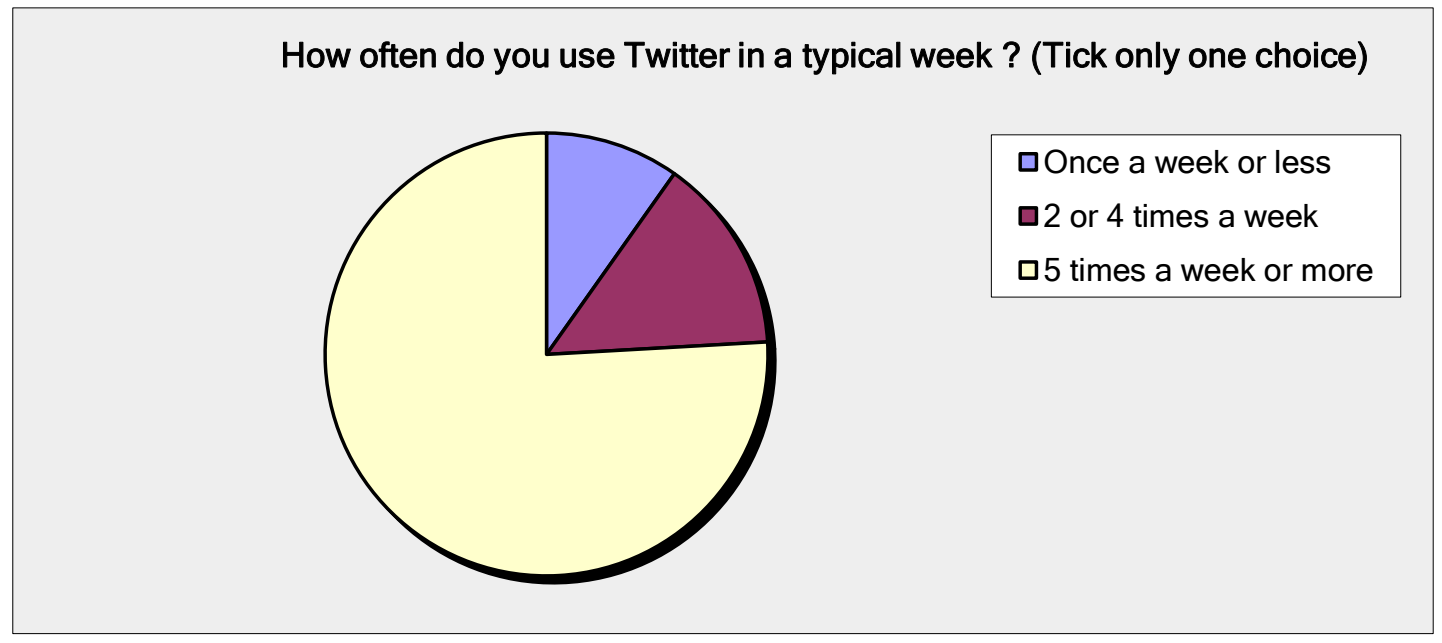

Figure 1: How often do you use Twitter in a typical week?

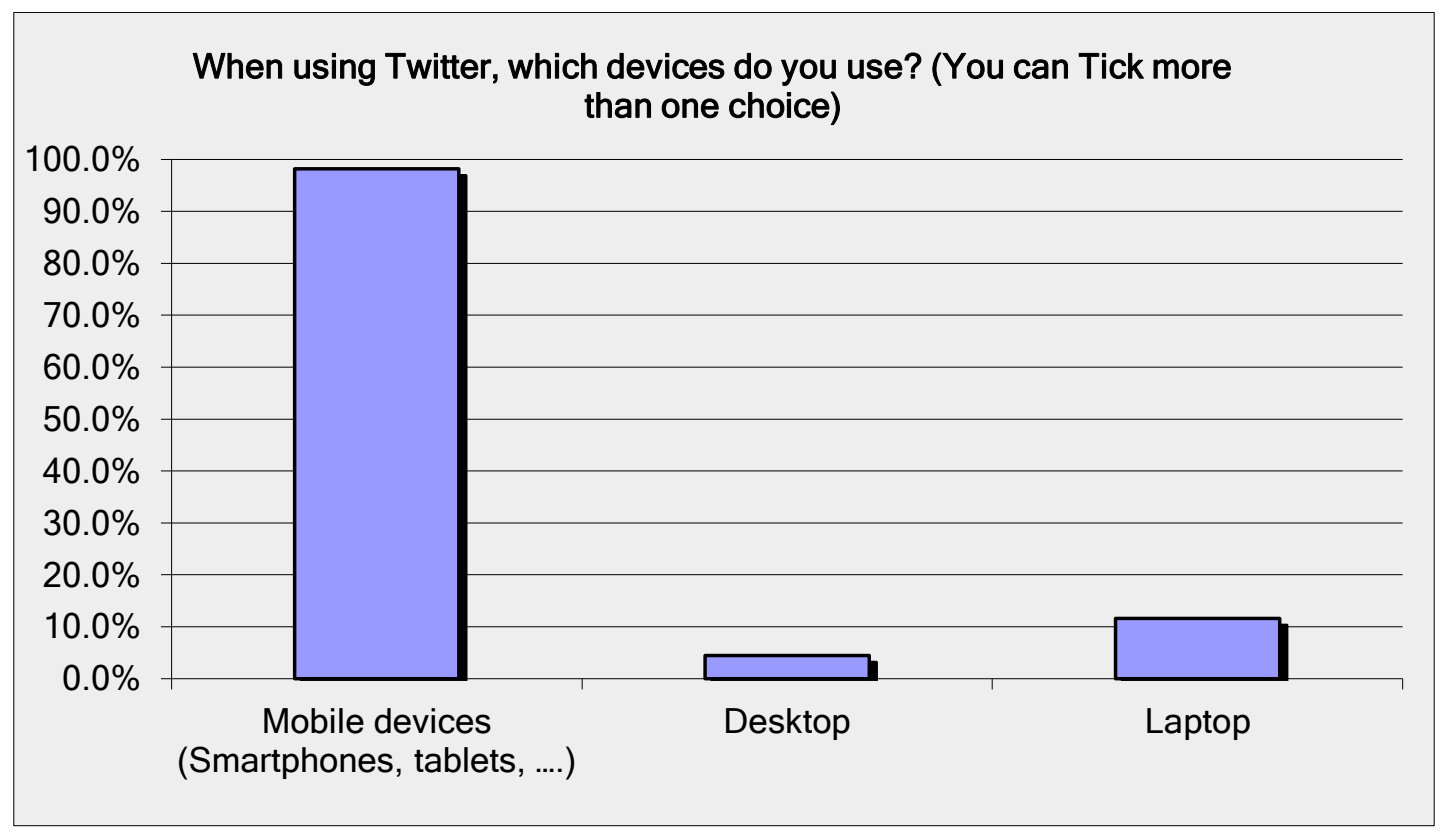

Figure 2: When using Twitter, which devices do you use? 
The qualitative data from the interviews confirms the existence of digital residence, where learners access Twitter whenever they need by using mobile devices. Participant MHI alluded to the notion of digital residents by saying, 'I access Twitter throughout an application on my mobile phone as it is easier and with me all the time especially when I am waiting for something'. This participant is likely online at all times, as Twitter can be accessed at any time and from any location. The quantitative data support this theory, as $98.2 \%$ (110) of participants claimed to access Twitter via mobile devices and 75.9\% (85) of participants reported using Twitter five times or more each week.

When asked how long they had been using Twitter (See Figure 3), 38.4\% (43) of participants responded with four years or more, while $26.8 \%$ (30) answered with three years, followed by the third cluster of $17.9 \%$ (20), who had used the platform for two years. Not surprisingly, the remaining two clusters were the smallest, with $10.7 \%$ (12) reporting that they had been using Twitter for only one year and 6.3\% (7) for six months. These results indicate that the majority $(83.1 \%$, or 93$)$ of participants have used Twitter for two years or more, suggesting that those surveyed have vital digital skills, to include accessing, evaluating, and managing information, as well as engaging regularly on social networking platforms.

The same participants indicated that they employed a variety of different social networks, which is evident in their responses to the question, 'What other social networks do you use?' The largest cluster of participants $(77.7 \%$, or 87$)$ reported using YouTube in addition to Twitter, followed by $68.8 \%$ (77) indicating Instagram, $53.6 \%$ (60) using Snapchat, 49.1\% (55) accessing Facebook, and 8.9\% (10) frequenting blogs. An additional 25\% (28) reported that they used a social network other than those that had been mentioned. (See Figure 4). 


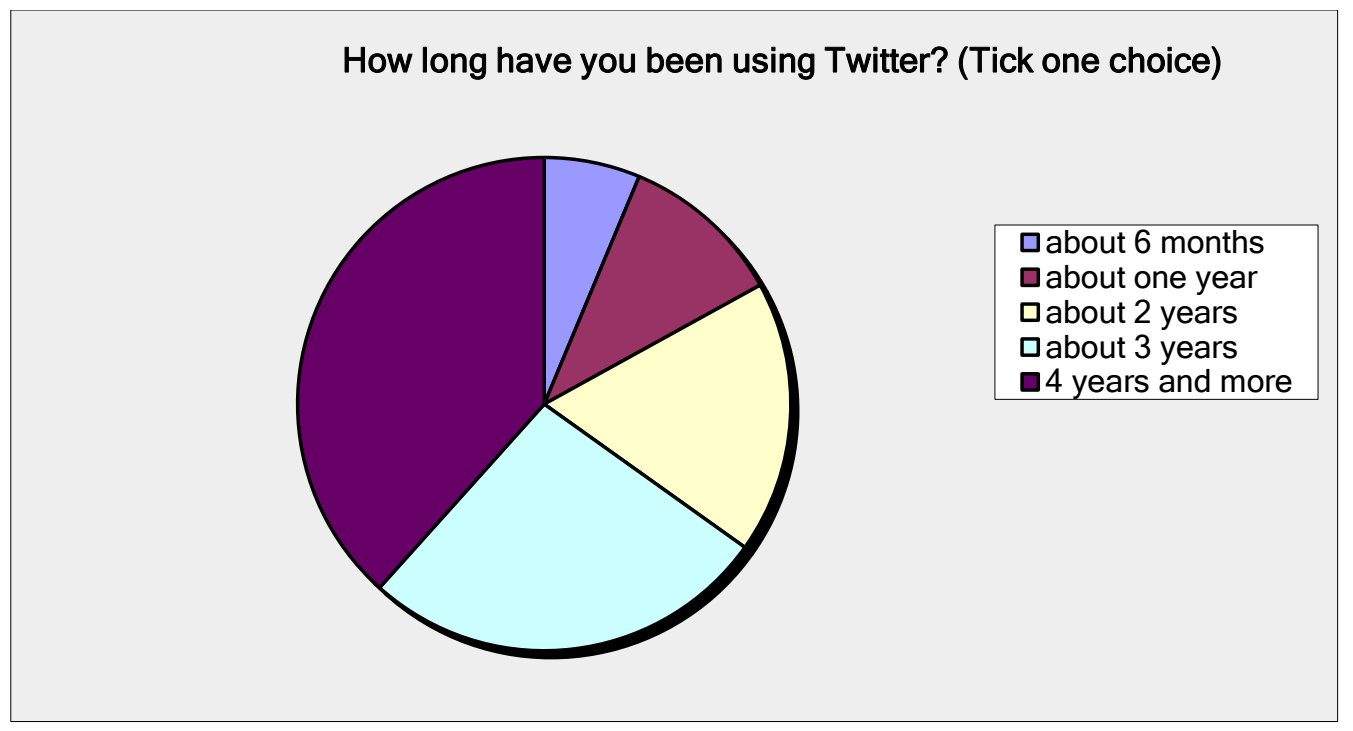

Figure 3: How long have you been using Twitter?

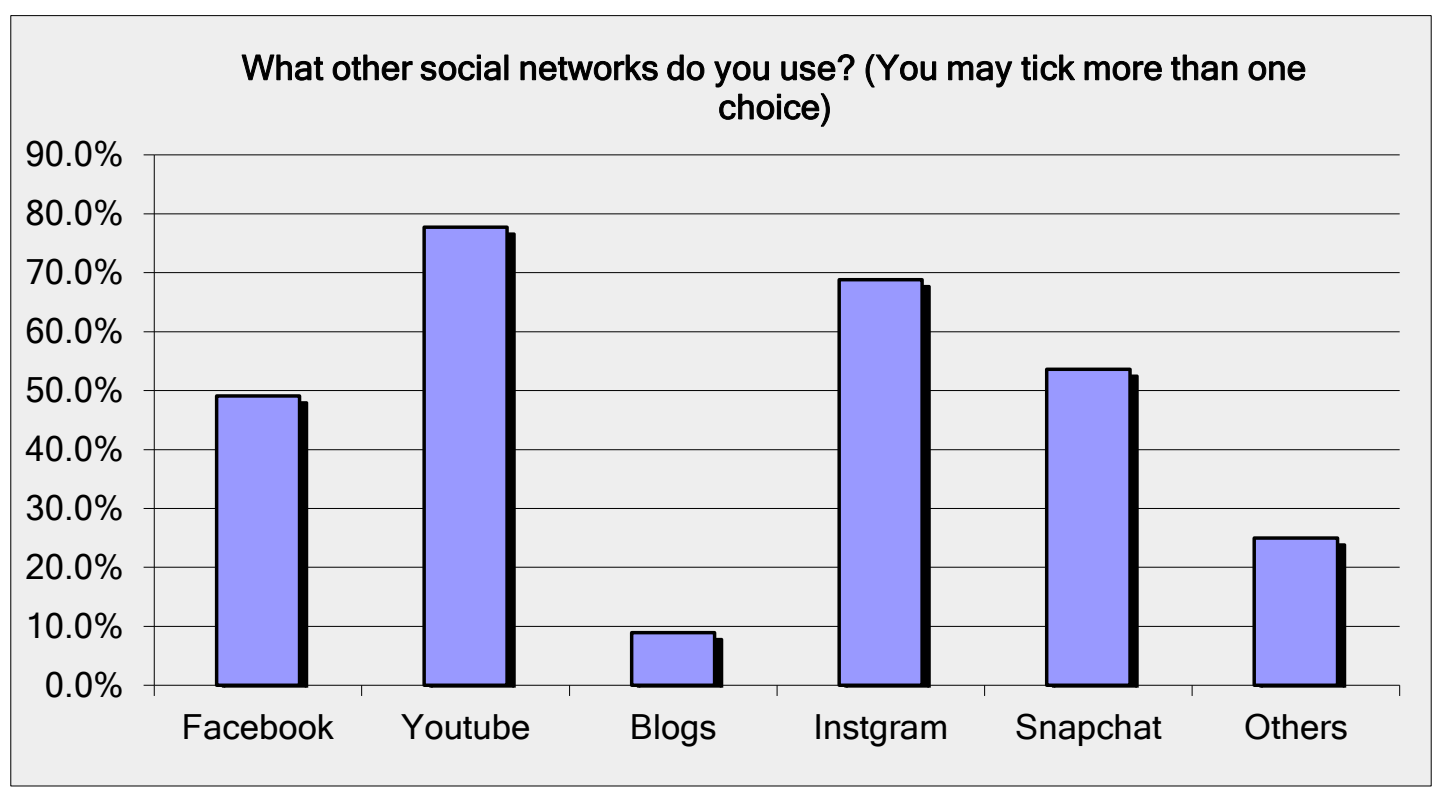

Figure 4: What other social networks do you use?

\subsection{The Use of Twitter for English Language Learning}

The second section of the questionnaire involved the crux of the study: the use of Twitter in English language learning. The graphic indicates that $83.9 \%$ (94) of participants used Twitter for English language learning; however, respondents differed in the amount of time they spent on the platform during each individual use. As it is seen in figure 5, 29.5\% (33) of participants used Twitter for English language 
learning five times a week or more, followed by $27.7 \%$ (31) who used it two or three times a week, and $26.8 \%$ (30) who only accessed it once a week or less. The $16.1 \%$ (18) of participants who have not used Twitter for this purpose were excluded from the last section of the questionnaire, although one of these respondents was selected to be interviewed during the qualitative phase of the study to find out why they had not used Twitter to learn English.

The randomly chosen interviewee, BFN, responded, 'I have not used Twitter in English language learning because my language is not that bad' and 'I will use Twitter to learn different languages such as French and Italian but not English.' These responses indicate that the reason for abstaining from English acquisition via Twitter was due not to the platform's ineffectiveness, but rather to the participant's perceived lack of need. The same interviewee added, 'I will encourage my husband and my brother to use Twitter in English language learning,' revealing that she believed Twitter could be an effective tool for learning English.

Among those who use Twitter for English language acquisition, there are five clear clusters in terms of the period that participants have been using the platform. Figure 6 indicates that $41.5 \%$ (39) of the 94 participants had been using Twitter for the purpose of English language learning for less than one year, constituting the largest cluster. This group was followed by $11.7 \%$ (11) who had been using it for one year, then $25.5 \%$ (24) for two years, and $10.6 \%$ (10) for both three years and four years or more. One interviewee, MMI, said, 'I used Twitter for English language learning after arriving at the UK,' implying that he recognized the importance of using Twitter for English acquisition upon arriving in the UK. 
How often do you use Twitter in English language ( Including; either consciously practising or using it unconsciously to pick up English ) ? (Tick one choice)

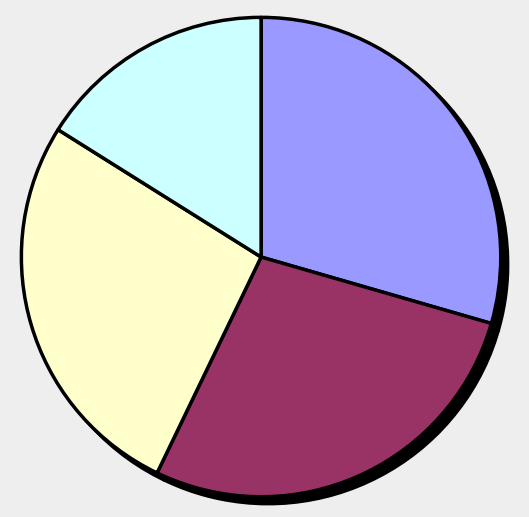

$\square 5$ times a week or more

$\square 2$ or 3 times a week

口Once a week or less

$\square$ Never

Figure 5: How often do you use Twitter in English?

How long have you been using Twitter for the purpose of English language learning? (Tick only one choice)

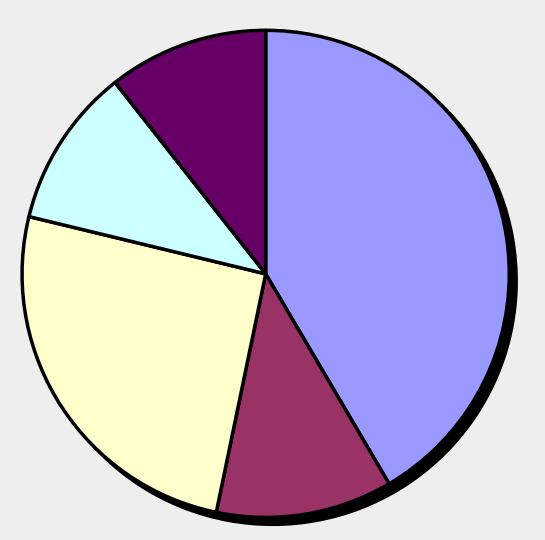

口Less than 1 year

1 year

$\square 2$ years

$\square 3$ years

$\square 4$ years and more

Figure 6: How long have you been using Twitter for English language learning?

Regarding the language that participants used when employing Twitter outside of their formal studies, over half of the 94 surveyed (53.2\%, or 50) indicated that they used both English and Arabic, whereas 42.6\% (40) stated that they used Arabic. Only $4.3 \%$ (4) participants used Twitter apart from their studies in English, and one interviewee, MMI, commented that 'I never used Twitter in classroom, I only used it 
outside classroom in English language to get the most updated news and to communicates with others.' (see Figure 7).

There is a notable difference when respondents were asked which language they preferred when using Twitter to improve or practice English. Nearly two-thirds of the respondents $(61.7 \%$, or 58) agreed that they used the English language only to improve and practice English through Twitter while it was 4.3\% (4/94) for those who use English language when using Twitter outside their studies and not for English learning. Of the 94 participants who completed this question, just nine of them $9.6 \%$ indicated using only Arabic language whereas it was $42.6 \%$ in the previous question. Less than a third of those who responded $28.7 \%$ (27/94) indicated that they used both Arabic and English language when they utilized Twitter in order to improve and practice English. This gives a clear evidence that they do not only learn English but they use it as well. (see Figure 8)

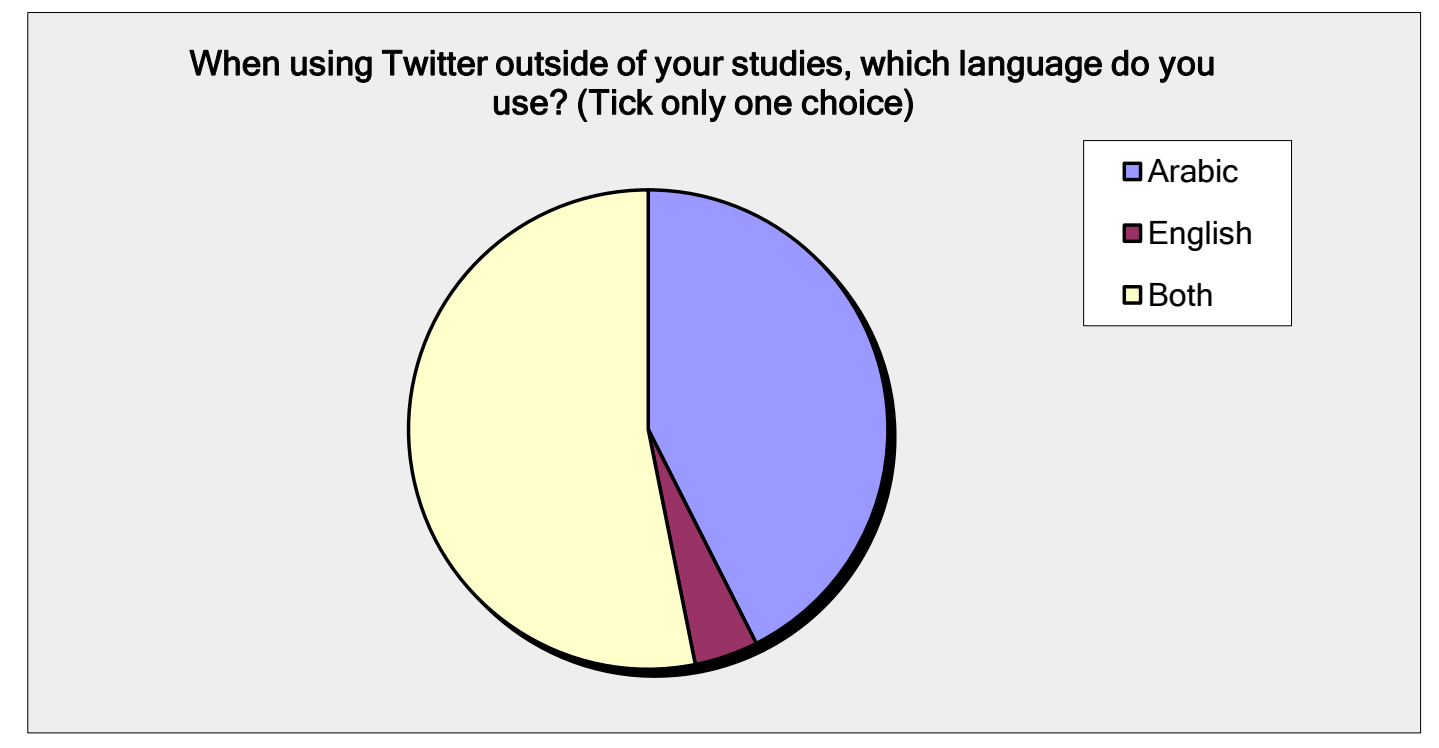

Figure 7: When using Twitter outside your studies, which language do you use? 
When using Twitter to improve and practice your English, which language do you use? (Tick only one choice)

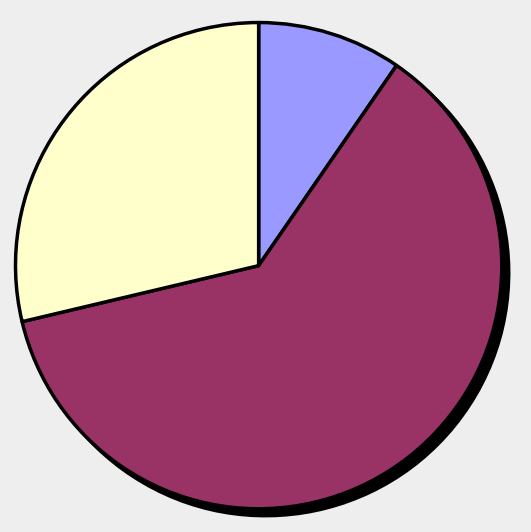

$\square$ Arabic

口English

aBoth

Figure 8: When using Twitter to improve and practise your English, which language do you use?

When doing activities to improve and practice your English such as following accounts, reading tweets and tweeting in hashtags, which language do you use? (Tick only one choice)

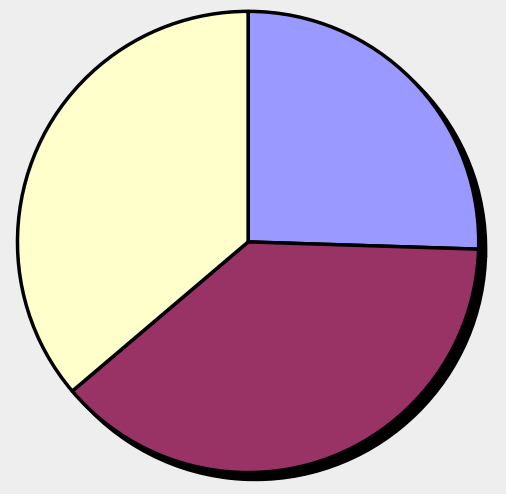

口Arabic

口English

口Both

Figure 9: When doing activities to improve and practise your English, which language do you use?

\subsection{Informal Learning}

In response to the question, 'When using Twitter for English language learning, where do you use it?,' $70.2 \%$ (66) of 94 respondents reported that they used 
Twitter outside of the classroom, while $21.3 \%$ (20) indicated that they used it both outside and within the classroom. Not surprisingly, only $8.5 \%$ (8) of participants reported that they used Twitter inside the classroom. Of particularly interest is the fact that a large number of the participants $(70.2 \%)$ claimed to use Twitter for English language acquisition outside of the classroom, in addition to the number that used it both inside and outside. These results indicate that the greatest demand for informal English learning occurs outside of the classroom, as evidenced by one interviewee's response, 'One of the main difficulties in learning English language insides classroom in most schools of English in the UK is the boring routine of teaching, they just give us the coursebook and teach us randomly' (MMH). These results indicate that informal learning is preferred by learners as it is more interesting and motivating.

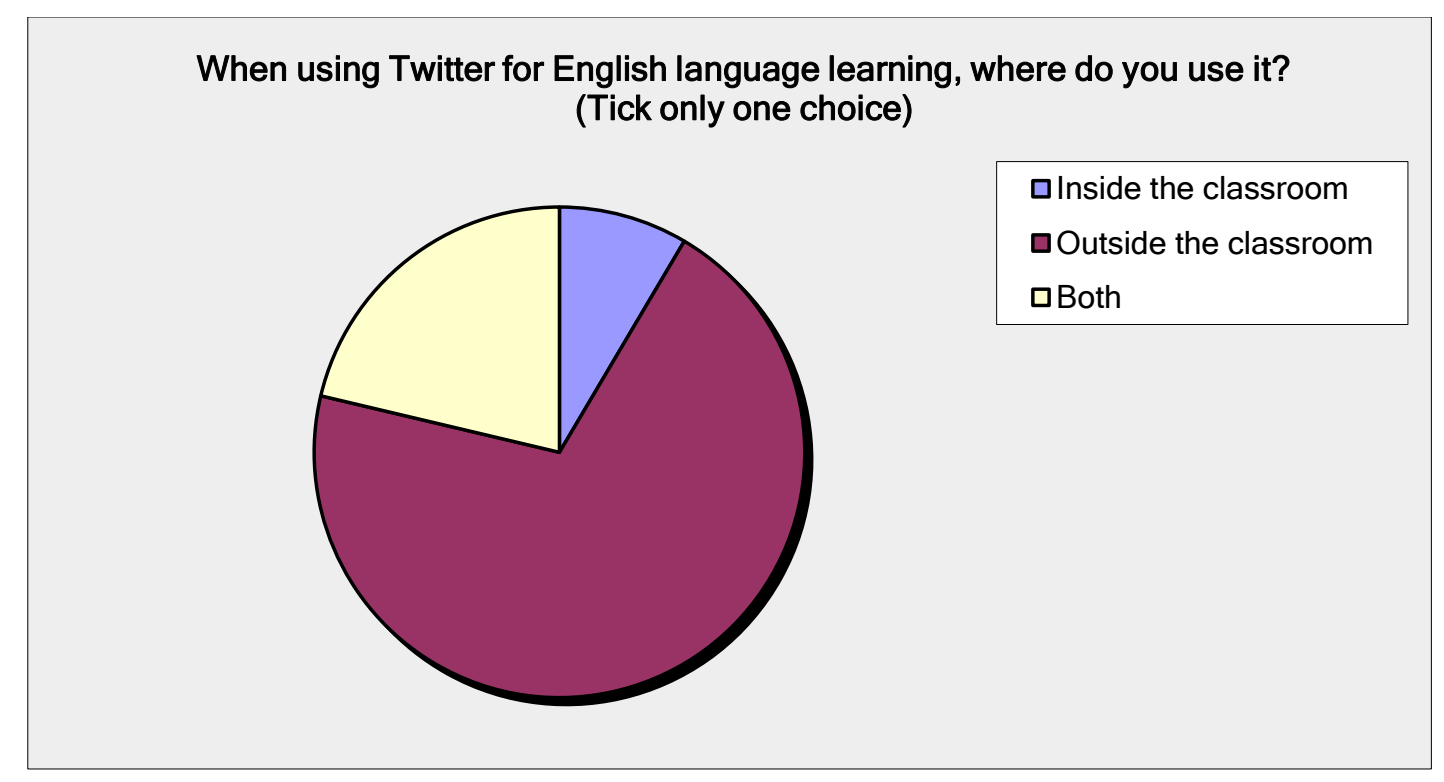

Figure 10: When using Twitter for English language learning, where do you use it? 


\subsection{Twitter Features}

\subsubsection{Multimedia}

A variety of Twitter multimedia were highlighted by respondents as being advantageous or significant parts of their Twitter engagement, to include photos, videos, and links. Participant MMH said, 'These Twitter users post short videos and they are very useful,' later commenting that 'English language learning Twitter accounts present vocabulary by putting it in a sentence with the pronunciation in a short video' but noting, 'These videos are very useful but they are very short and I wish to be longer.' Another interviewee agreed that 'The 30-seconds-videos in Twitter help much as they short and interesting.'(MMI). These responses indicate that while most participants find multimedia to be a helpful asset, their preferences differ in regards to effective length of video.

\subsubsection{Anytime and Anywhere}

Twitter is unique to social media platforms in its ability to be accessed at any time and from any location through the use of electronic devices and, more importantly, through mobile devices such as smartphones, iPads, and some new smart watches. As long as Wi-Fi is available, learners can use Twitter anywhere and anytime, a fact which participant MMH notes when he says, 'As my mobile with me all the time I can access Twitter anytime and particularly waiting times,' adding that 'these Twitter users post everyday.' Another interviewee said that 'I sometime access Twitter when I am waiting for my order in the bus or in my freetime,' indicating that the ease and availability of Twitter is a considerable benefit of the platform which encourages individuals to use it often, including for the purpose of learning a language. 


\subsection{Motivation}

Participants were asked to indicate whether they have been requested by a teacher or a tutor to use Twitter outside of the classroom, for English acquisition purposes or otherwise. Over three-fourths $(76.6 \%$, or 72$)$ of the 94 participants said that they have not been asked by either a teacher or a tutor to use Twitter outside classroom for this reason, and $23.4 \%$ (22) reported that they had. (See Table 3)

Table 2: Have you ever been asked by a teacher to use Twitter outside the classroom?

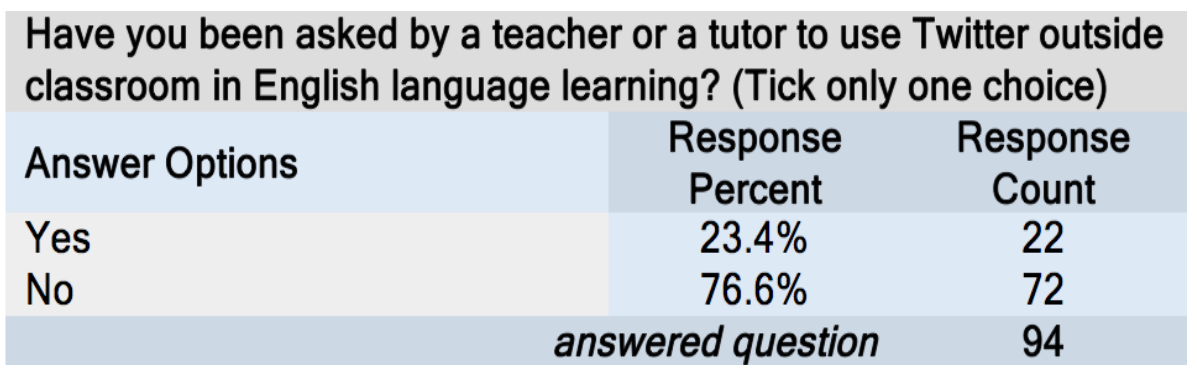

One interviewee, $\mathrm{MMH}$, commented that 'I have not encouraged by any teacher or tutor to use Twitter for the purpose of English language learning,' adding that 'I decided to use Twitter in English language learning as I found it interesting whereas my classes were boring.' Another interviewee, MMI, said, 'The motivation for using Twitter in English language learning comes from myself and some of my friends' advices,' and he added, 'Most of my friends here use Twitter to improve their language proficiency,' suggesting that the motivation is intrinsic and individuals are not forced to use Twitter for these purposes.

On the other hand, interviewee BFN said, 'I have joined Twitter three years ago because my $\mathrm{PhD}$ group encouraged me to do so as they are all on Twitter and they have some activities there but I am not that active,' adding that 'I have not used Twitter in English language learning because my language is not that bad.' Although she is on 
Twitter, this participant is not active, as she established an account merely to placate friends and colleagues.

\subsection{Learners' Needs}

English language learners have different needs, and those needs should be accommodated equally; however, this is generally impossible in a normal classroom setting, as classes are time sensitive and consist of many students with varying needs, learning styles, and motivations. Interviewee MMH alluded to this, saying, 'My tutor does not know what I am weak at and he treats us all the same where we are different,' insinuating that the classroom environment does not fulfil his needs. This participant found that Twitter might serve as a solution, commenting that 'I found Twitter significant because I can work on my weakness and focus on them.' Although she does not intend to use it to learn English specifically, another participant acknowledged the utility of Twitter, noting, 'I am thinking of using Twitter to learn another language but not English as I think my language proficiency is quite good' (BFN). She feels that Twitter might be used when there is a need for it.

Question 14 refers to the reasons behind using Twitter in English, where participants were asked to choose from the six answers given. As shown in Table .... , 48.9\% (46) of the 94 responding participants used Twitter as a way to practice and improve their language skills; 43.6\% (41) reported that they used Twitter in English to communicate with other people because English is the international language; $25.5 \%$ (24) indicated that they used Twitter in English to keep in touch with English speaker friends; and a $55.3 \%$ (52/94) of the participants included that they used Twitter to get the most current news. 
Table 3: Reasons for using Twitter in English

\begin{tabular}{|c|c|c|}
\hline Answer Options & $\begin{array}{l}\text { Response } \\
\text { Percent }\end{array}$ & $\begin{array}{c}\text { Response } \\
\text { Count }\end{array}$ \\
\hline $\begin{array}{l}\text { I use Twitter because it is a way to practice and improve } \\
\text { my language skills. }\end{array}$ & $48.9 \%$ & 46 \\
\hline $\begin{array}{l}\text { I use Twitter to communicate with other people because } \\
\text { English is the international language. }\end{array}$ & $43.6 \%$ & 41 \\
\hline $\begin{array}{l}\text { I use Twitter to keep in touch with English speaker } \\
\text { friends. }\end{array}$ & $25.5 \%$ & 24 \\
\hline I use Twitter to get the most updated news. & $55.3 \%$ & 52 \\
\hline To access language learning apps and websites. & $30.9 \%$ & 29 \\
\hline To discuss the role of English language with others. & $10.6 \%$ & 10 \\
\hline answered question & & 94 \\
\hline
\end{tabular}




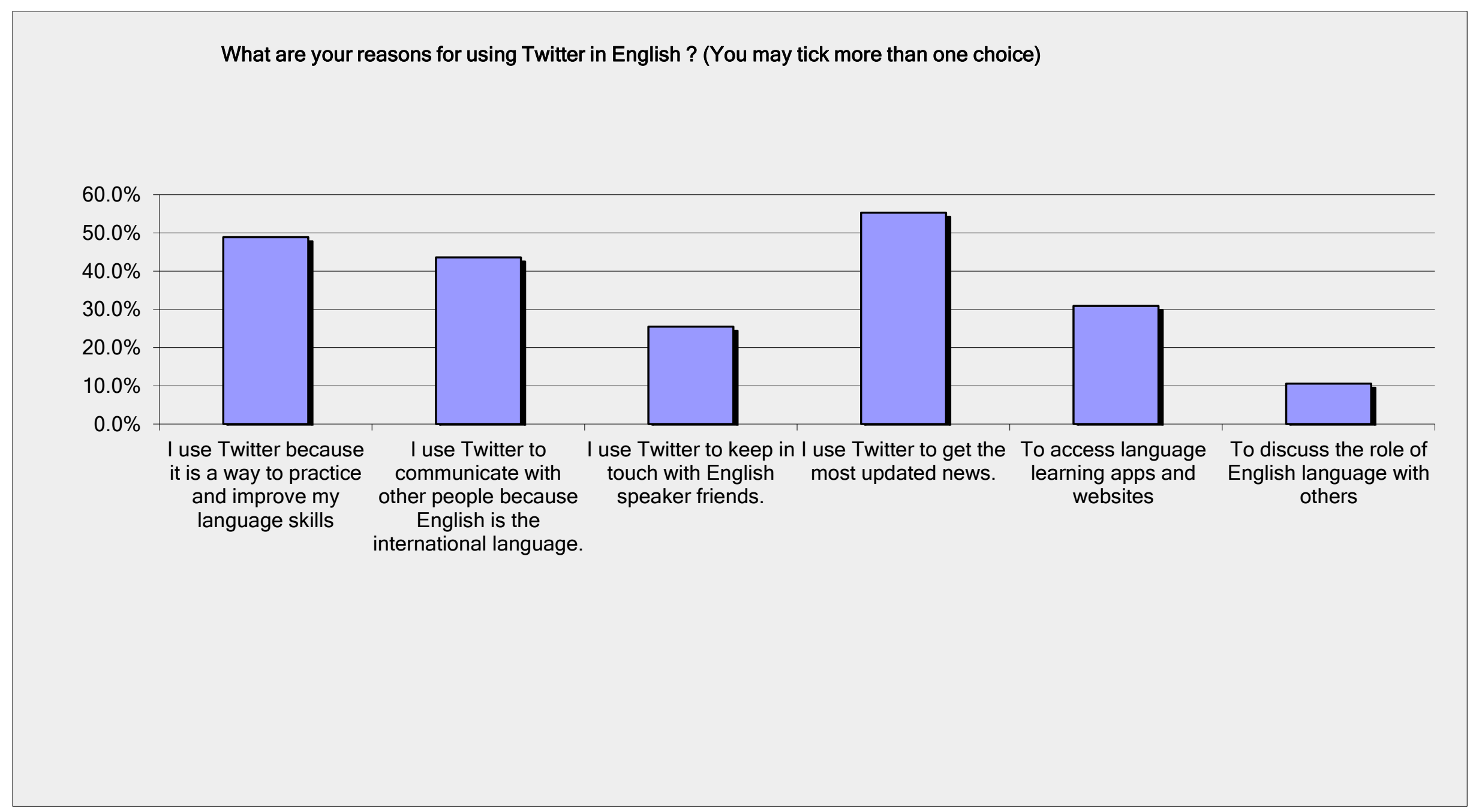

Figure 11: What are your reasons for using Twitter in English? 
The interviewee BFN said, 'I only used Twitter to get news' and participant MMI commented that 'I started using Twitter in 2011 to get the most updated news, then I used it more after coming to the UK as I have more time.' Using Twitter in English and following English Twitter accounts help leaners to improve their language subconsciously. The same interviewee (MMI) indicated this by saying that 'Twitter is a good place to practice English but not to learn as I follow account that tweet in English such as news accounts,' later explaining, 'I follow news Twitter account such as BBC (@BBCBreaking) to improve my language and I noticed that the reading skill has improved gradually.' Although some may not intentionally access the site to learn English, often times their acquisition of the language is a side effect of their interaction and engagement.

Learners generally prefer to use Twitter not exclusively for learning English, but also to interact with friends, colleagues, and families, as well as to obtain the most up-to-date news. Of 94 respondents, 30.9\% (29) stated that they used Twitter in English to access language learning apps and websites, while 10.6\% (10) reported that they used Twitter in English to discuss the role of the English language with others.

Although more than two-thirds of participants agreed that Twitter contributed to their enhanced English language proficiency to varying degrees, some claimed that Twitter helped them improve more than others. Interviewee MMH commented that 'Listening is the most skills that has been improved by the use of Twitter in English language learning,' whereas participant MMI said, 'I found that my writing has devolved as a results of reading English Tweets,' adding, '...but Twitter does not help me to improve my listening.' When asked for the reasoning behind his response, participant $\mathrm{MMH}$ said that 'English language learning Twitter accounts present vocabulary by putting it in a sentence with the pronunciation in a short video'; 
however, interviewee MMI responded to the same question by saying that "All of these videos present easy vocabulary and pronunciation which I know them all and that does not improve my listening skill.' Interviewee BFN contributed by saying, 'My writing skill is quite weak and I might use Twitter to improve it' and when she was asked why she thought that might be helpful, she replied, ' $\ldots$ as the character of tweeting is limited to 140 which might help improve my writing.' Participant BFN preferred the character limit because it forces her to be concise and to the point which consequently will improve the writing skills.

Participants reported in Question 15 that they coupled their Twitter use with other social networks in the English acquisition process. This question differs from the previous item regarding social media use in that Question 15 asks for the information in the specific context of English language acquisition. The largest cluster of responses was YouTube, which constitutes 74.5\% (70) of the 94 participants' responses. Facebook came second, with $38.3 \%$ (36) of participants, followed by Instagram at $43 \%$ (32), and then Snapchat with $33 \%$ (31). Blogs were the smallest cluster, selected by only $10.6 \%$ (10) of the participants, and the last cluster was identified as Others, with $23.4 \%$ (22) reporting that they used social networks other than those listed in the process of learning the English language. 


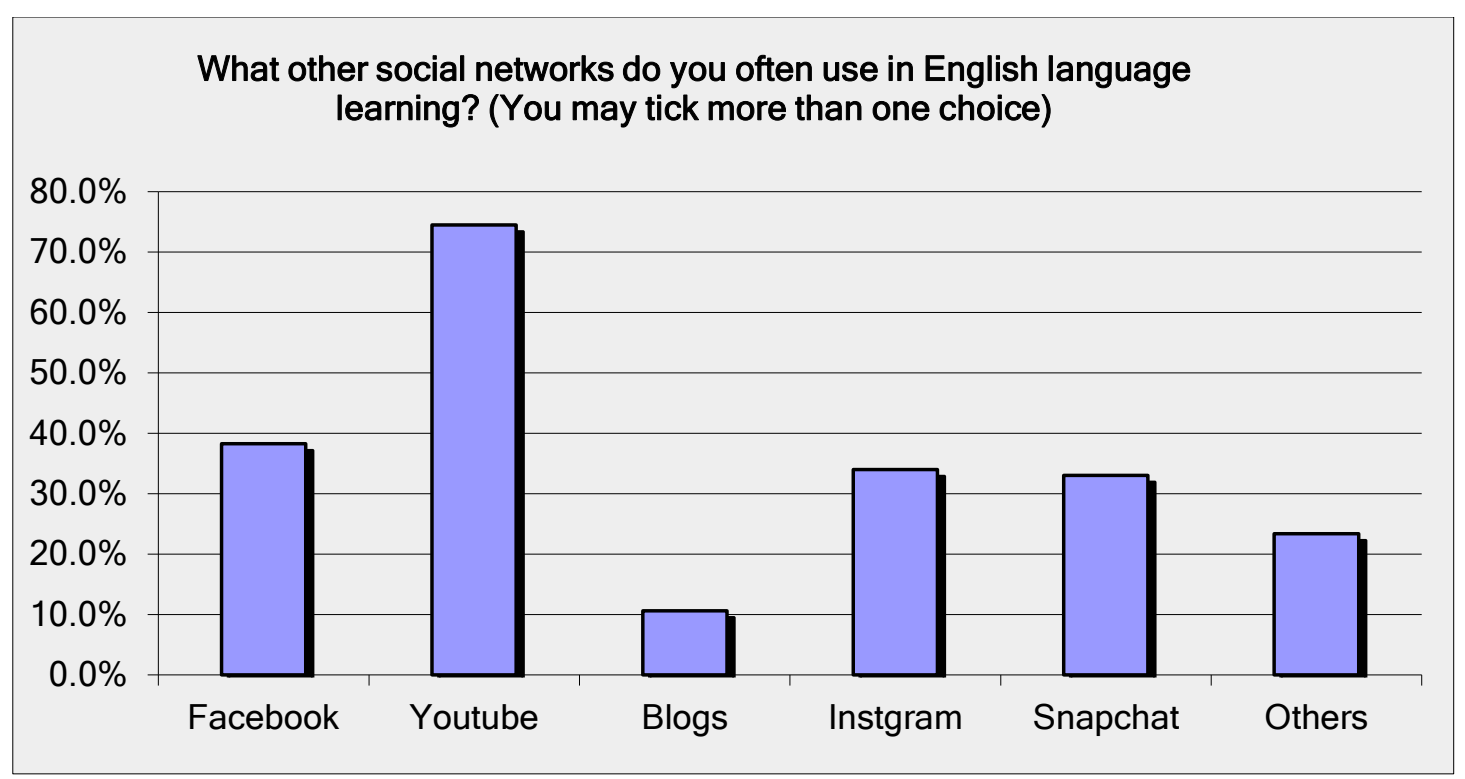

Figure 12: What other social networks do you often use in English language learning?

\subsection{Vocabulary}

While the information was not formally or explicitly pursued by the researcher, during the interview phase every participant alluded to the importance of learning English terminology through the use of Twitter. Interviewee MMH said that 'I have learned many stuff in Twitter such as phrases, idioms and daily vocabulary and this by the virtue of such accounts,' and another participant, MMI, added that 'Using Twitter helped to learn many vocabulary and reading them frequently contributed in memorising them.' Presenting new vocabulary frequently, Twitter helped students to learn new words through repeated exposure, demonstrating its contribution to enhanced vocabularies, whether consciously or subconsciously.

Participant BFN supported this theory, claiming, 'I have learned some vocabulary from Twitter, Instagram and Facebook but I have found them accidently where my friends and accounts I follow shared them or retweeted them,' and interviewee MMI added, 'When I found something useful or new words I mention my friends on Twitter to the tweets or to the Twitter account that tweet about English and 
I retweeted them,' a process by which others are exposed to new vocabulary whether they are interested in English language learning or not.

One individual, MMI, stated, 'If I find any new vocabulary, I just copy it and use Google translator to check what it means'. Interestingly, interviewee MMH said, 'Sometimes, I use Twitter in classroom if I want to look up for some new vocabulary,' implying that Twitter can also be used as a reference guide to look up and better understand novel words. The same interviewee explained a helpful language-oriented feature, whereby 'English language learning Twitter accounts present vocabulary by putting it in a sentence with the pronunciation in a short video and translate them in Arabic'.

\subsection{Efficiency of Using Twitter for English Language Learning}

In regard to Statement 12, 'I believe that using Twitter helps me practice and/or learn English,' participants' perceptions were mainly affirmative. Over half of those surveyed $(60.6 \%$, or 57$)$ reported that they agreed with the statement, while $21.3 \%$ (20) strongly agreed. By contrast, only $4.3 \%$ (4) of the participants disagreed with the statement, and $1.1 \%$ (1) strongly disagreed. The remaining minority $(12.8 \%$, or 12$)$ indicated that they were unsure of whether Twitter helped them in practicing and/or learning English. One interviewee, MMH, said, 'My language proficiency has improved after using Twitter in learning English,' but added, 'I only use Twitter to learn English but not to practice.' This statement implies that Twitter is being used as a tool for English language learning for those whose language proficiency is at the intermediate or basic levels, as the same participant commented that 'practising English is a high level that I do not reached it yet.' Practice comes once acquisition is complete. 
Responses to the statement 'I believe that my English language proficiency has been improved by using Twitter' were divided into six clusters, and differed noticeably among participants. Over half of the 94 participants $(51.1 \%$, or 48$)$ asserted that they agreed with the statement, while $12.8 \%$ (12) strongly agreed with the same statement.

This was clear when interviewee MMI said that 'I am addicted to Twitter, I spend about 5 hours a day on Twitter, and this helped to improve my language and learn some new vocabulary.' The same individual added that many of his friends felt similarly: 'I thinks Twitter is really amazing in learning English and I know many friends of mine whose their language proficiency has developed because of using Twitter.' Another interviewee, $\mathrm{MMH}$, commented that 'My experience of using Twitter in English language learning is much better than formal learning in normal classes, I have learned many stuff in Twitter such as phrases, idioms and daily vocabulary and this by the virtue of such accounts.'

In contrast, $11.7 \%(11)$ reported that they disagreed with the above statement, while only $3.2 \%$ (3) indicated that they strongly disagreed, and a substantial $21.3 \%$ (20) of participants asserted that they were unsure of whether their English proficiency had improved as a result of using Twitter. 
I believe that using Twitter helps me practice and/or learn English. (Tick only one choice)

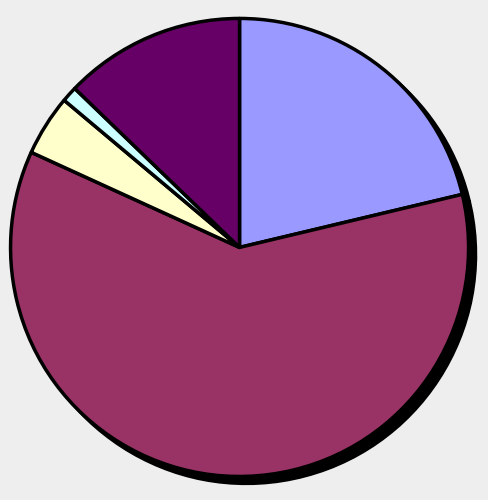

口Strongly Agree 口Agree 口Disagree $\square$ Strongly Disagree aNot sure

Figure 13: Does Twitter help with English practice and/or learning?

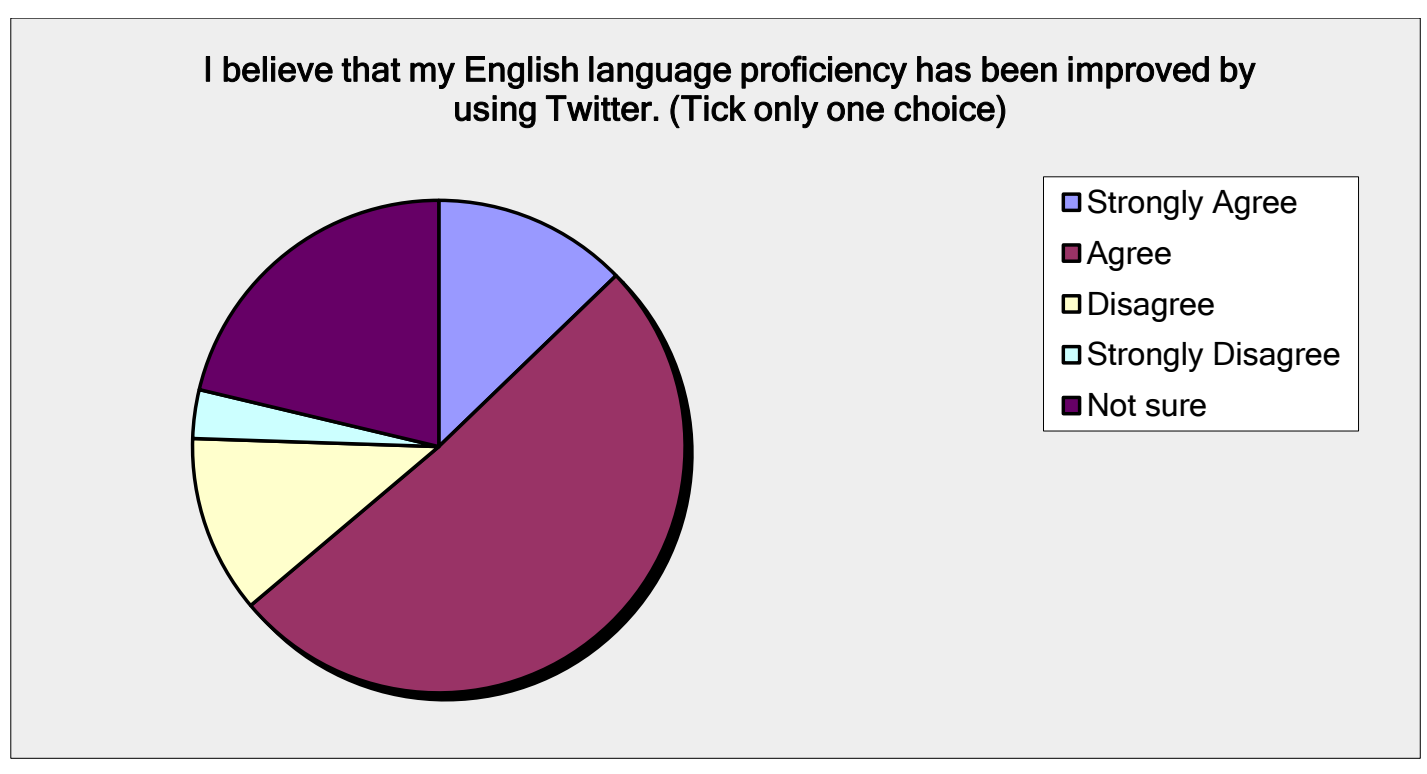

Figure 14: Is your English language proficiency improved by Twitter?

\subsection{Digital Literacy}

As previously mentioned, digital literacy skills can help English learners use Twitter effectively and efficiently in their language acquisition process, as evidenced when learners are fully engaged on Twitter. Although it is common practice, participant $\mathrm{MMH}$ reported that he never uses hashtags or participates in them: 'I have not visit any hashtags in Twitter, I just follow some Twitter accounts.' When asked in 
the interview, 'Do you tweet in English?,' he replied 'No, I have not reached this stage yet.'

Another participant, MMI, commented that 'I do not regularly tweet or mention others, I just read tweets and retweet them and that just to benefit my followers.' The same participant reported that 'I have not participated in hashtags for English language learning,' indicating a lack of digital literacy in terms of hashtag use. Interviewee BFN said that 'I sometime found my posts tweeted to public where it is meant to be private for my friends or I just searched for it,' signalling either a fear of social media repercussions or a lack of digital literacy in the first place. 


\section{Chapter Five: Conclusion}

\subsection{Conclusion}

The present study investigated the perceptions and practices of adopting Twitter in English language learning by adult Saudi students in the UK. The study focused on adult Saudi students, reporting their use of Twitter for the purpose of learning English and uncovering their feelings and opinions towards the social media platform.

Collected data show that adult Saudi students in the UK are digital residents in the sense that they can - and do - access Twitter anytime and anywhere via various mobile devices. Twitter was found to be an effective and useful tool for learning and practicing English language skills, whether consciously or unconsciously. Learners' perceptions regarding the efficiency and effectiveness of Twitter in English language learning were positive, and results showed that adult Saudi students with high English proficiencies tended to employ Twitter to practice the language, often unconsciously, while those with low proficiencies used it to consciously learn the language in the first place.

In an increasingly global society, social media has been vital to exposing millions of users to worldwide events. Social media users are more connected than ever, able to witness international news in real time and engage in discussions concerning major issues with people from all across the globe; however, the capabilities of social media do not end there. These platforms, particularly microblogging sites like Twitter, enable users to actively seek out language instruction, immerse themselves in a new language through relevant conversation, or 
unconsciously absorb a new language merely by participating in online discourse with native speakers.

The implications of this phenomenon expand much further than social media hype, reaching educators and policymakers throughout the world. The present study focused on one aspect of this process - the perception of Twitter as a language acquisition tool for adult Saudi speakers in the UK - but future research would do well to extend these findings to other populations, demographics, and social media spheres.

\subsection{Further Research}

Although this study contributes to the TESOL field by providing insight into the use and effectiveness of Twitter in language acquisition, specifically English, it cannot possibly answer every question or fill every gap. Due to its small scale size and very specific sample population, the present research is unable to capture every nuance of the Twitter-language dynamic, leaving these questions unanswered and gaps unfilled. Findings do suggest that while its intended purpose was to serve as a vehicle for online communication, Twitter has been informally adopted as a valuable language acquisition tool, demonstrating the fluidity and adaptability of social media.

A comparison study might be useful in future research, examining the difference in language acquisition efficiency between those who used Twitter prior to language learning and those who had had no previous contact with the platform. The results of this dichotomy might uncover the importance of digital literacy prior to embarking upon the language acquisition process online.

While this study focused on one specific demographic and its response to a particular social media platform, future research would do well to consider expanding the process used here to other demographics and online applications. A number of 
social media sites have the ability to aid in language acquisition, and it will be important to identify those programs in order to maximize their educational potential. 


\section{References}

Alexa. (2015). Twitter.com site information. Retrieved 5 October, 2015, from http://www.alexa.com/siteinfo/twitter.com

Aspden, E. J., \& Thorpe, L. P. (2009). Where do you learn? Tweeting to inform learning space development. Educause Quarterly, 32(1). Retrieved 10 September, 2015, from http://er.educause.edu/articles/2009/3/where-do-youlearn-tweeting-to-inform-learning-space-development

Bax, S. (2003). CALL - Past, present and future. System, 31(1), 13-28.

Belshaw, D. (2007). 3 scenarios for using Twitter with your students. Retrieved 19 October, 2015, from http://tinyurl.com/2lvtvf

Bonwell, C. C., \& Eison, J. A. (1991). Active learning: Creating excitement in the classroom. ASHE-ERIC Higher Education Report no. 1. Washington, DC: George Washington University.

Borau, K., Ullrich, C., Feng, J., \& Shen, R. (2009). Microblogging for language learning: Using Twitter to train communicative and cultural competence. In M. Spaniol, Q. Li, R. Klamma, R. W. H. Lau, (Eds.), Advances in web-based learning (pp.78-87). Berlin, Germany: Springer.

Brown, J. D. (2001). Using surveys in language programs ( $1^{\text {st }}$ ed.). New York, NY: Cambridge University Press.

Bull, G., Thompson, A., Searson, M., Garofalo, J., Park, J., Young, C., \& Lee, J. (2008). Connecting informal and formal learning: Experiences in the age of participatory media. Contemporary Issues in Technology and Teacher Education, 8(2), 100-107. Retrieved 7 November, 2015, from http://www.citejournal.org/vol8/iss2/editorial/article1.cfm

Cherney, I. D. (2008). The effects of active learning on students' memories for course content. Active Learning in Higher Education, 9(2), 152-71.

Cohen, L., Manion, L., \& Morrison, K. (2007). Research methods in education (6 $^{\text {th }}$ ed.). London, UK: Routledge.

Conley, S., Lull, K., \& Monsalve, L. (2010). What is social media and what can it do for me? NASN School Nurse, 25(2), 70-71.

Creswell, J. (2009). Research design: Qualitative, quantitative, and mixed method approaches ( $3^{\text {rd }}$ ed.) Los Angeles, CA: Sage.

Cummins, J. (2000). Academic learning, transformative pedagogy, and information technology: Towards a critical balance. TESOL Quarterly, 34, 537-548.

De Waal, E., \& Schoenbach, K. (2010), News sites' position in the medias cape: Uses, evaluations and media displacement effects over time, New Media \& Society, 12(3), 477-496. 
Denzin, N. K., \& Lincoln, Y. S. (1994). Handbook of qualitative research. Thousand Oaks, CA: Sage.

Denzin, N. K., \& Lincoln, Y. S. (2003). The discipline and practice of qualitative research. In N. K. Denzin \& Y. S. Lincoln (Eds.), Collecting and interpreting qualitative materials ( $2^{\text {nd }}$ ed.) (pp. 1-45). Los Angeles, CA: Sage.

Dickens, S. (2008). Twitter - microblogging. Digitalang. Retrieved 5 October, 2015, from http://www.digitalang.com/2008/04/twitter-microblogging

Dörnyei, Z. (2003). Questionnaires in second language research: Construction, administration, and processing. London, UK: Lawrence Erlbaum.

Dörnyei, Z. (2007). Research methods in applied linguistics: Quantitative, qualitative, and mixed methodologies. Oxford, UK: Oxford University Press.

Dörnyei, Z., \& Taguchi, T. (2009). Questionnaires in second language research: Construction, administration, and processing. London, UK: Routledge.

Downes, S. (2007). Learning networks in practice. In D. Ley (Ed.), Emerging technologies for learning (vol. 2). Coventry, UK: Becta. Retrieved 24 November, 2015 from http://nparc.cisti-icist.nrc-cnrc.gc.ca/npsi/ctrl?lang=en

Driscoll, M. (2000). Psychology of learning for instruction. Needham Heights, MA, Allyn \& Bacon.

Dudeney, G., Hockly, N., \& Pegrum, M. (2013). Digital literacies: Research and resources in language teaching. Harlow: Pearson Education Limited.

Dunlap, J. C., \& Lowenthal, P. R. (2009). Tweeting the night away: Using Twitter to enhance social presence. Journal of Information Systems Education, 20(2), 18.

Ebner, M., Lienhardt, C., Rohs, M., \& Meyer, I. (2010). Microblogs in higher education - a chance to facilitate informal and process-oriented learning? Computers and Education, 55(1), 92-100.

Educause. (2007). 7 things you should know about Twitter. Retrieved 7 November, 2015 , from http://www.educause.edu/ELI/7ThingsYouShouldKnowAboutTwitt/161801

Faizi, R., El Afia, A., \& Chiheb, R. (2014). Social media: An optimal virtual environment for learning foreign languages. International Journal of Emerging Technologies in Learning, 9(5), 64-66.

Fraij, I. (2015). The state of Saudi Arabia social media. Retrieved 7 November, 2015, from https://www.linkedin.com/pulse/state-saudi-arabia-social-media-ibrahim

Garrett, N. (2009). Computer assisted language learning trends and issues revisited: Integrating innovation. The Modern Language Journal, 93(s1), 719-740. 
Grosseck, G., \& Holotescu, C. (2008). Can we use Twitter for educational activities? Paper presented at the $4^{\text {th }}$ International Scientific Conference eLSE: eLearning and Software for Education, Bucharest, Romania, April 17-18. Retrieved 26 October, 2015, from https://adlunap.ro/else/

Hockly, N., \& Dudeney, G. (2013). Digital literacies. Harlow, UK: Pearson.

Holotescu, C., \& Grosseck, G. (2011). Mobile learning through microblogging. Procedia - Social and Behavioral Sciences, 15, 4-8.

Huberman, B., Romero D. M., \& Wu, F. (2008) Social networks that matter: Twitter under the microscope. Retrieved 30 October, 2015, from http://www.hpl.hp.com/research/scl/papers/twitter/

Internet World Stats. (2015). World Internet users and 2014 world population stats. Retrieved from 14 June, 2015, http://www.internetworldstats.com/stats.htm

Jarvis, H. (2014). Digital residents: Practices and perceptions of non native speakers. Asian EFL Journal, 75, 21-35.

Jarvis, H., \& Achilleos, M. (2013). From computer assisted language learning (CALL) to mobile assisted language use. TESL-EJ, 16(4), 1-18. Retrieved 17 August, 2015, from http://tesl-ej.org/wordpress/issues/volume16/ej64/ej64a2/

Jick, T. (1979). Mixing qualitative and quantitative methods: Triangulation in action. Administrative Science Quarterly, 24(4), 602-611.

Johnson, D. M. (1992). Approaches to research in second language learning. New York, NY: Guilford Publications.

Johnson, R., \& Onwuegbuzie, A. (2004). Mixed methods research: A research paradigm whose time has come. Educational Researcher, 33(7), 14-26.

Kelley, S. (2010). Texting, Twitter contributing to students' poor grammar skills, profs say. The Globe and Mail. Retrieved 5 October, 2015, from http://www.theglobeandmail.com/news/technology/texting-twittercontributing-to-students-poor-grammar-skills-profs-say/article1452300/

Kern, R., (2006). Perspectives on technology in learning and teaching languages. TESOL Quarterly 40(1), 183-210.

Kolb, D. (2014). David Kolb - University of Leicester. Retrieved 7 November, 2015, from http://infed.org/mobi/david-a-kolb-on-experiential-learning/

Krashen, S. (1982). Principles and practice in second language acquisition. London, UK: Pergamon.

Kvale, S. (1996). Interviews: An introduction to qualitative research interviewing. Thousand Oaks, CA: Sage. 
Lee, H. J., \& Rha, I. (2009). Influence of structure and interaction on student achievement and satisfaction in web-based distance learning. Educational Technology \& Society, 12(4), 372-382.

Levy, M. (2009). Technologies in use for second language learning. The Modern Language Journal, 93(s1), 769-782.

Livingstone, K. A. (2012). The Importance of feedback and reinforcement in Computer-Assisted Language Learning (CALL). Baraton Interdisciplinary Research Journal, 2(1), 43-51.

Lu, L. C., \& Yeh, C. L. (2008). Collaborative e-learning using semantic course blog. International Journal of Distance Education Technologies, 6(3), 1-12.

Luo, T., \& Gao, F. (2012). Enhancing classroom learning experience by providing structures to microblogging based activities. Journal of Information Technology Education: Innovations in Practice, 11(1), 199-211.

Mackey, A., \& Gass, S. M. (2005). Second language research: Methodology and design. Mahwah, NJ: Lawrence Erlbaum.

Mackley, D. (2014) What is a personal learning network/environment? Retrieved 19 August, 2015, from http://blog.yorksj.ac.uk/moodle/2014/05/13/what-is-apersonal-learning-network/

Madge, C., Meek, J., Wellens, J., \& Hooley, T. (2009). Facebook, social integration and informal learning at university: 'It is more for socialising and talking to friends about work than for actually doing work'. Learning, Media and Technology, 34(2), 141-155.

Marsick, V. J., \& Watkins, K. E. (1990). Informal and incidental learning in the workplace. London, UK: Routledge.

Mazer, J. P, Murphy, R. E, \& Simonds, C. J. (2007). I'll see you on 'Facebook': The effects of computer-mediated teacher self-disclosure on student motivation, affective learning, and classroom climate. Communication Education, 56(1), 117.

Mazer, J. P., Murphy, R. E., \& Simonds, C. J. (2009). The effects of teacher selfdisclosure via Facebook on teacher credibility. Learning, Media \& Technology, 34(2), 175-183.

Meskill, C., \& Anthony, N. (2010). Teaching languages online. Bristol, UK: Multilingual Matters.

Murray, L., \& Hourigan, T. (2006). Using micropublishing to facilitate writing in the foreign language. In N. Arnold \& L. Ducate (Eds.), Calling on CALL: From theory and research to new directions in foreign language teaching (pp. 149179). San Marcos, TX: CALICO Monograph Series 5. 
National School Board Association. (2007). Creating and connecting: Research and guidelines on online social-and educational-networking. Retrieved 10 September, 2015, from https://www.nsba.org/sites/default/files/reports/CREATING-CONNECTINGResearch-and-Guidelines-on-Online-Social-and-Educational-Networking.pdf

Oppenheim, A. (2001). Questionnaire design, interviewing and attitude measurement. London, UK: Continuum.

Parry, D. (2008). Twitter for academia. AcademHack. Retrieved 5 October, 2015, from http://academhack.outsidethetext.com/home/2008/twitter-for-academia/

Patton, M. (2002). Qualitative research and evaluation methods ( $3^{\text {rd }}$ ed.). London, UK: Sage.

Peerreach. (2015). Peerreach: Join the right conversation with the right people. Retrieved 17 November, 2015, from https://peerreach.com

Pew Research Centre. (2014). Social networking fact sheet. Retrieved 3 December, 2015, from http://www.pewinternet.org/fact-sheets/social-networking-factsheet/

Selwyn, N. (2009). Faceworking: Exploring students' education-related use of Facebook. Learning, Media and Technology, 34(2), 157-174.

Siemens, G. (2005). Connectivism: A learning theory for the digital age. International Journal of Instructional Technology \& Distance Learning 2(1). Retrieved 1 December, 2015, from http://www.itdl.org/journal/jan_05/article01.htm

Statistic Brain. (2015). Twitter statistics. Retrieved 13 November, 2015, from http://www.statisticbrain.com/twitter-statistics/

Tess, P. A. (2013). The role of social media in higher education classes (real and virtual) - a literature review. Computers in Human Behavior, 29(5), A60-A68. Retrieved 17 October, 2015, from http://dx.doi.org/10.1016/j.chb.2012.12.032

Trifanova, A., Knapp, J., Ronchetti, M., \& Gamper, J. (2004). Mobile ELDIT: Challenges in the transitions from an e-learning to an m-learning system. Trento, Italy: University of Trento. Retrieved 20 November, 2015, from http://eprints.biblio.unitn.it/532/1/paper4911.pdf

Tsai, P. J., Hwang, G. J., Tseng, C. R., \& Hwang, G. H. (2008). A computer assisted approach to conducting cooperative learning process. International Journal of Distance Education Technologies, 6(1), 49-66.

Twitter. (2015). Twitter reports third quarter 2015 results. Retrieved 3 November, 2015, from https://investor.twitterinc.com/results.cfm

Utecht, J. (2008). How to create a personal learning network. Tech \& learning, 28(10), 52.

Veletsianos, G. (2011). Designing opportunities for transformation with emerging 
technologies. Educational Technology, 51(2), 41.

Veletsianos, G., \& Kimmons, R. (2013). Scholars and faculty members' lived experiences in online social networks. The Internet and Higher Education, 16, 43-50.

Vygotsky, L. S. (1985). Thought and language. Cambridge, MA: The M.I.T. Press.

Wheeler, S. (2009). Teaching with Twitter: Learning with 'e's. Retrieved 5 October, 2015, from http://steve-wheeler.blogspot.fr/2009/01/teaching-with-twitter.html

White, D., \& Cornu, A. (2011). Visitors and residents: A new typology for online engagement. First Monday, 16(9). Retrieved 24 November, 2015, from http://firstmonday.org/article/view/3171/3049

Yang, Y. F. (2011). Engaging students in an online situated language learning environment. Computer Assisted Language Learning, 24(2), 181-198.

Young, M. M. (2010) Twitter me: Using micro-blogging to motivate teenagers to exercise. In R. Winter, J. L. Zhao \& S. Aier (Eds.) Global perspectives on design science research (pp. 439-448). Berlin, Germany: Springer. 


\section{Appendices}

\section{Appendix 1: Screenshots of Twitter Users}

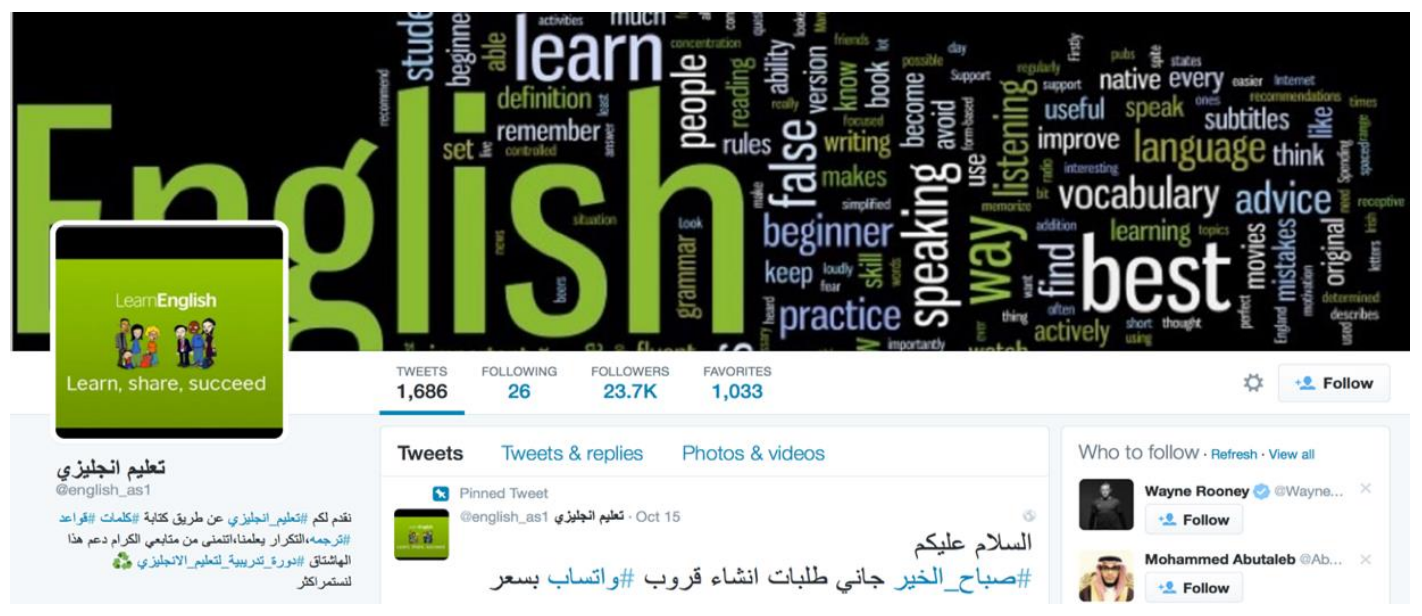

Figure 1

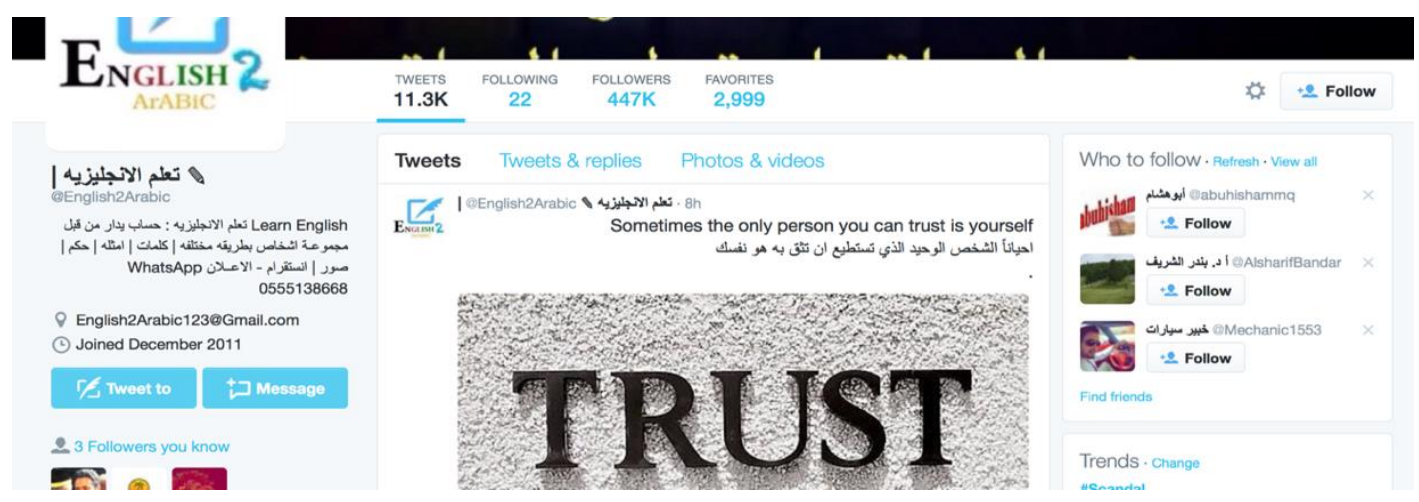

Figure 2

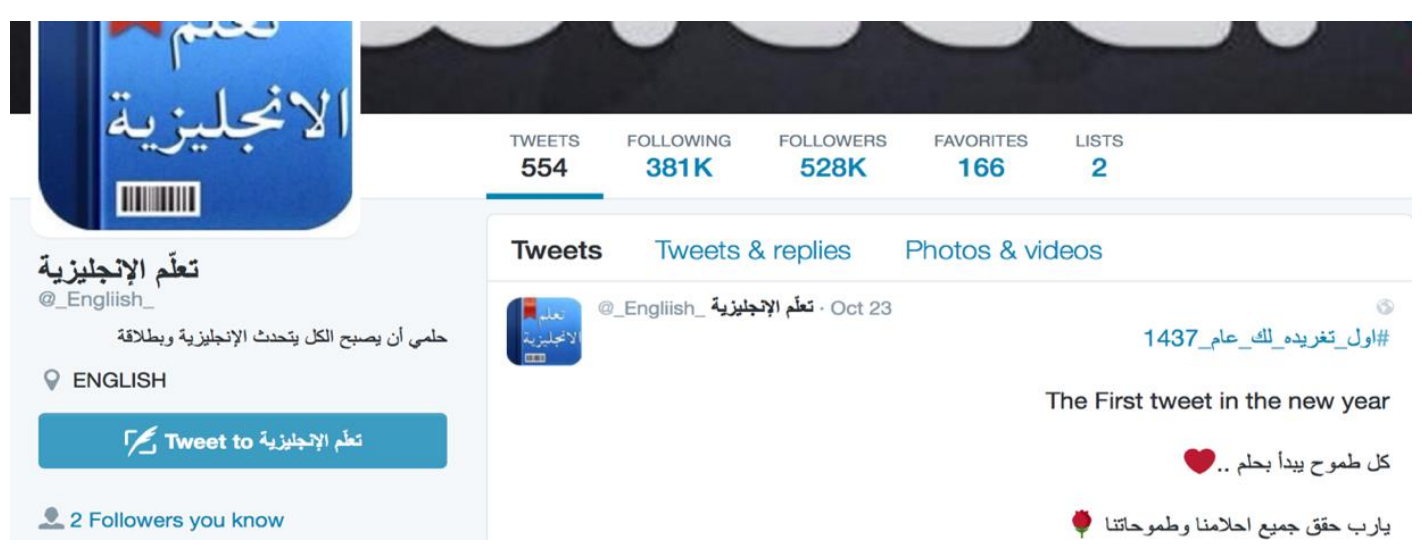

Figure 3 
Appendix 2: Screenshots of different tweets

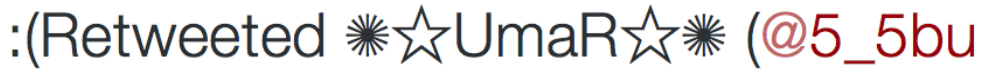
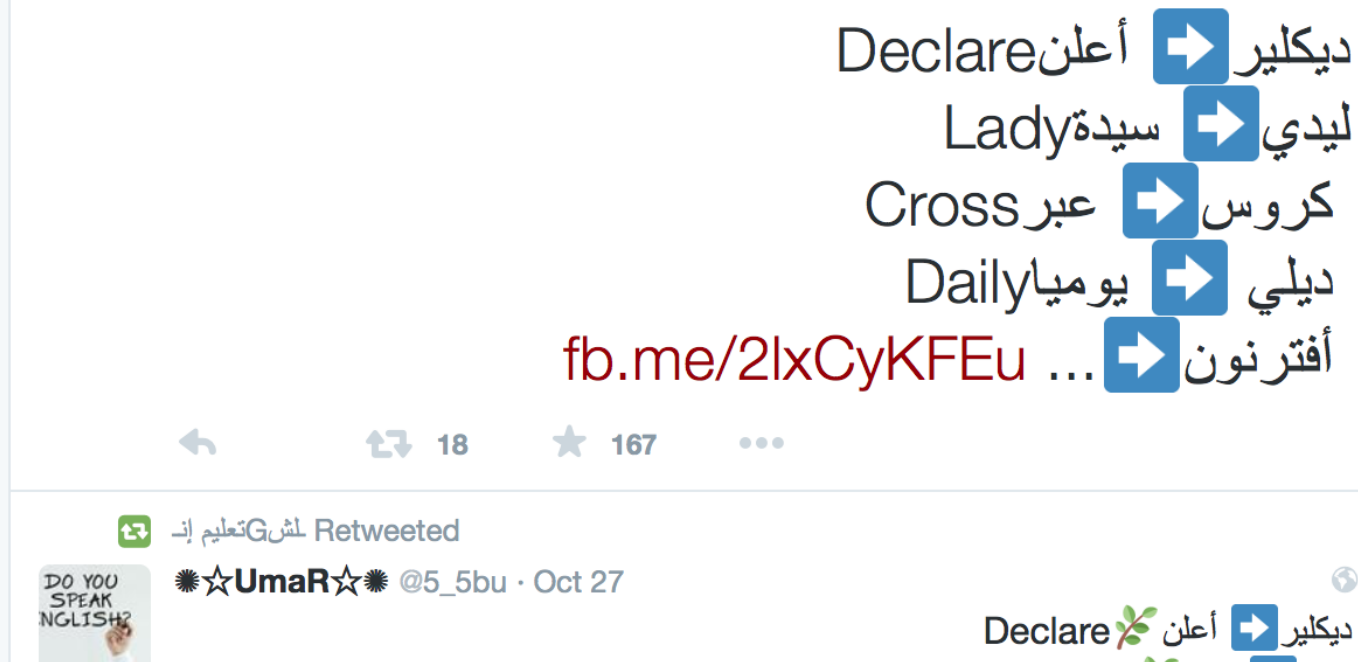

Figure 1 


\section{يدير - يجري = Run}

The manager runs the company.

المدير يدير الشركة.
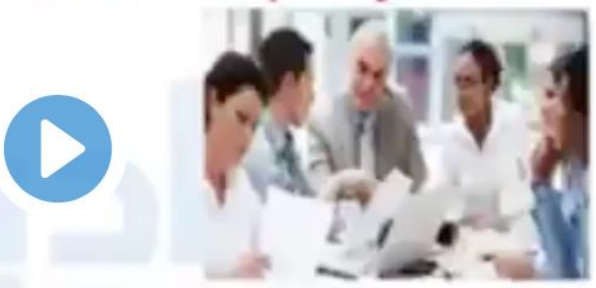

The boy runs quickly.

الولد يجري بسرعة.

\section{@English4ardaily}

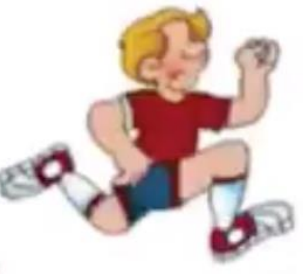

0.15

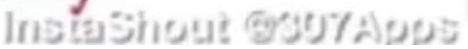

Figure 2

تعليم إنـ5bu Dec 1

ซื

I'd like to report a theft

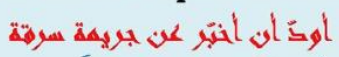

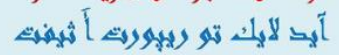

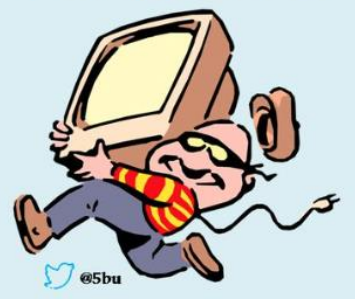

Please hurry!

أسرج أربوكن

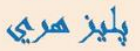

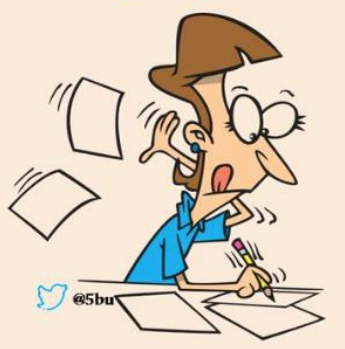

h

느 72

○ 63

Figure 3 

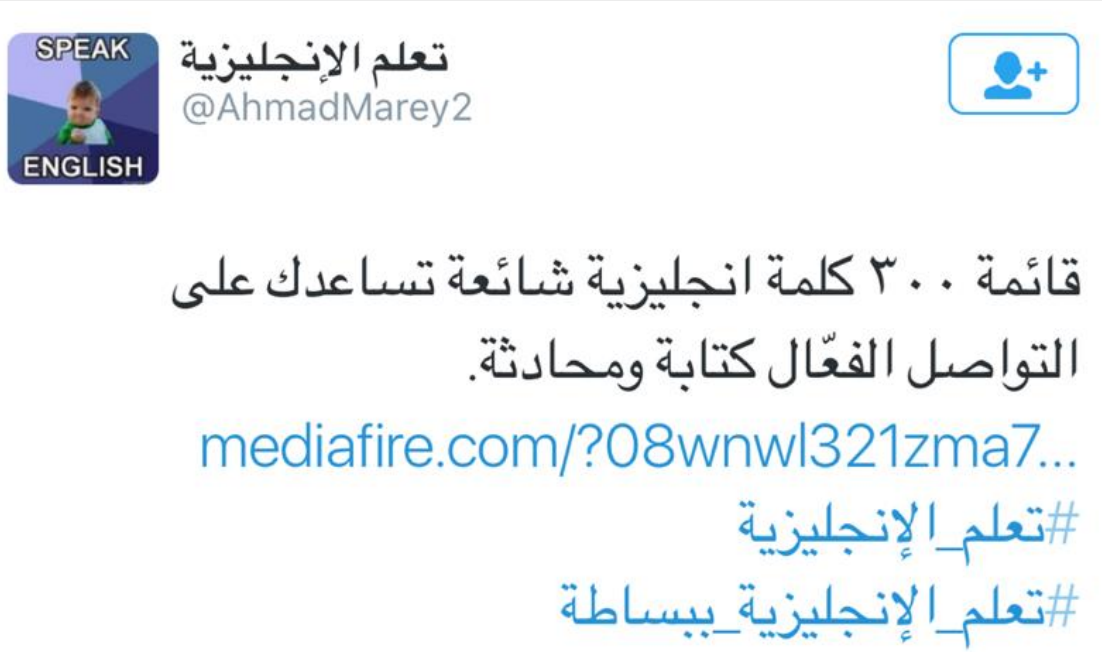

Figure 4 


\section{Appendix 3: Interview Transcription}

This is an indicative sample for one of the three interviewees who participated in this study

Interview Sample of Manchester Male I (his initial) MMI

Red: Researcher

Black: MMI

ـأهلا وسهال أخوي معنا في هذه المقابلة.

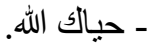

- طبعا مثلما تعلم هذه المقابلة عن استخدام تويثر في تعلم الإنجليزية من قبل السعوديين في المملكة المتحدة،

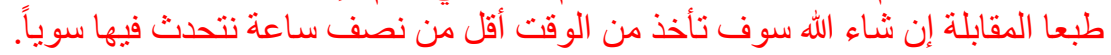

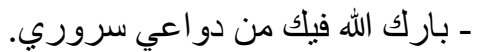

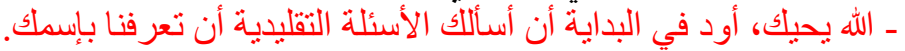
مبتعث من برنامج خادم الحرمين الثريفين.

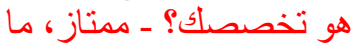

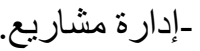

- و الماجستير انتهيت من داريت دارسته ما شاء الله؟ ـ ـ نعم من فضل الله و اليوم ستكون الدرجات.

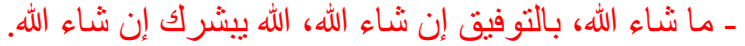

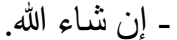

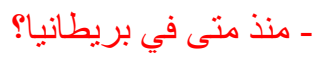

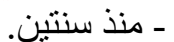

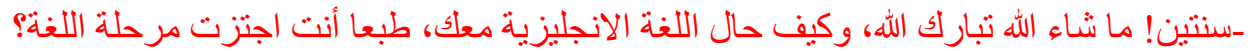
ـ نعم اجتزتها بكثير، فقد كانت دراستي في البكالوريوس كلها باللغة الإنجليزية فهذا ساعدني كثير اً. - في السعودية؛ - نعم.

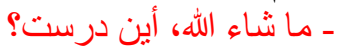
ـ في جامعة الأمير محمد بن فهد فكانت در استي من الصفر حتى تخرجنا باللغة الانجليزية في البداية عانينا في

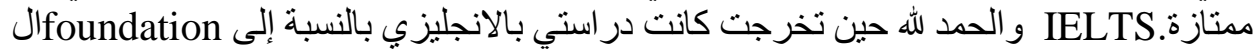

ـ ـ ما شاء الله. معاء.

! s و Salford university نعم أول اختبار لي فيها كان 5.5 و عند قدومي إلى بريطانيا تقدمت لامتحانين في واجنزتهم.English institution - وبدأت بالماجستير؟

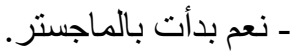

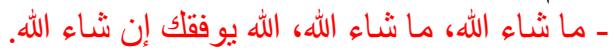
ـ الله يخليك. ـ أريد أن تحدثني عن تجربتك في تويثر بشكل عام، منذ منى فيها؟ منى دخلت؟ منى فتحت حساب؟ كيف طريقة استخدامك للتويثر؟ تصني ـ سجلت للمرةٍ الأولى في تويتر عام 2012، 2011، مابين

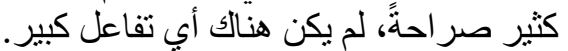

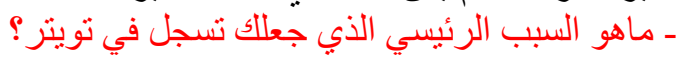
-As a social media - تقصد تجربة" ـ نعم تجربة، في البداية أقر أ بعض الأحبان إعلانات، بعض الأحبان أخبار ، أول بأول دائماً. 
ـ مع الوقت بدأت أتعلق حتى أصبح شيء روتيني يجب أن أدخل عليه، هذا مع الوقت لكن في البداية لأ، لم أكن active.

$$
\text { - ماهي نو عية الحسابات التي تتابعها؟ }
$$

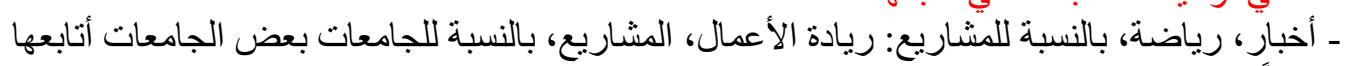

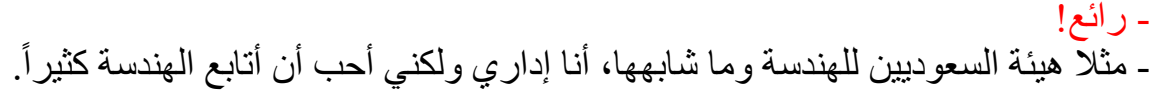

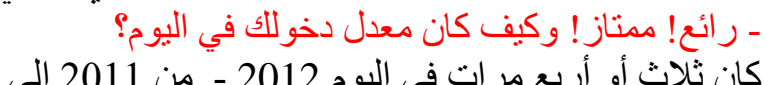

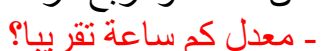
- ماعة - ماعة - ماعة

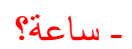

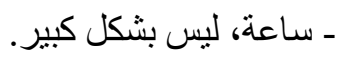

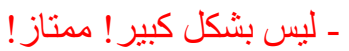
ـ عام 2014 إلى الإنى 2015 في بريطانيا امتلكت وقت فراغ إغ أكبر، ففي السعودية وقت الفر اغ أقل و السبب وجود الأهل و الإخوان و الأصدقاء و الجماعة و الدو ام بعض العض الأحيان.

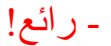
- في بريطانيا وقت الفراغ أكبر فأصبحت أدخل على تويتر كثير.

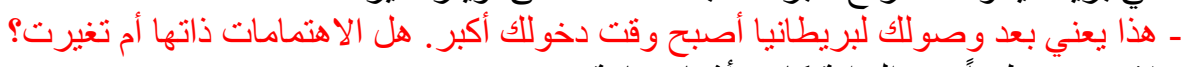
ـ ـ لا تغيرت طبعاً، في البداية كانت أنشياء عامة.

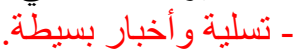

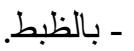

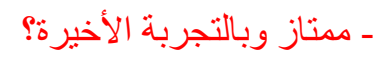

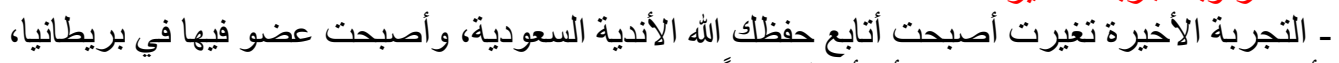

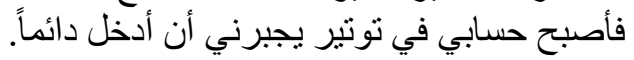

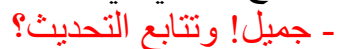
ـ نعم أتابع التحديثات أُول بأول، بالنسبة للأنشطة، و المؤتمر ات، وماذا حدث هنا وهناك، و أذهب أشنارك،

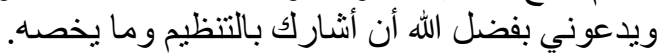

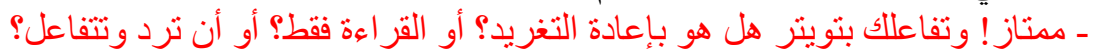

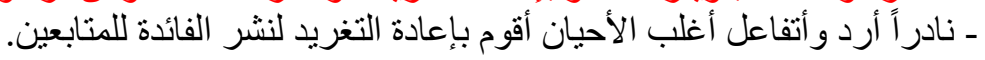

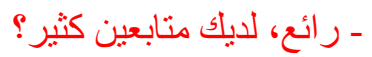

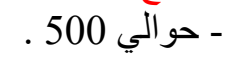
ـ ـ ـمتاز، روالي رائع! هل في صعوبات في تجربتلك الأولى وتجربتلك الآن في تويتر بشكل عام؟ ـ ماذا تشعر الفائدة التي استفدتها؟ ـ مثلما أخبرتك؛ العجيب في نويتر التحديثات جداً سريعة القرار ات اتلبات الملكية تعرفها بسر عة في تويتر، القرار ات الملحقية، الثباب يتناقلون الآخبار بسر عة التبرة

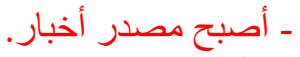
ـ بالضبط! في بعض الأحبان الأحيان موثوق، فمثلاً تصدق الأخبار في تويتر و لا تصدقها في الواتس أب. ـ عجيب! صدقت لأنها حسابات رسمية نقريباً التي تعلن.

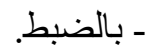

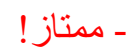

ـ مصداقية اصحاب الحسابات مصداقية قديمة، أب شاهدناها في المستقبل، أي مثلا: بعد اسبو عين سوف يحدث

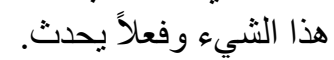

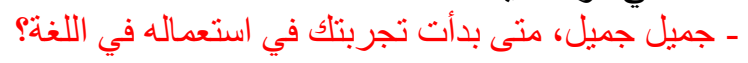


-في منتصف عام 2014.

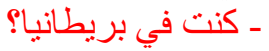

ـ ـعم كان في حساب نسيت إسمه جميل جداً يعطيك قصة بسيطة للأطفال تقر أها، طبعاً.

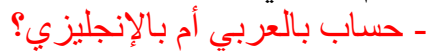

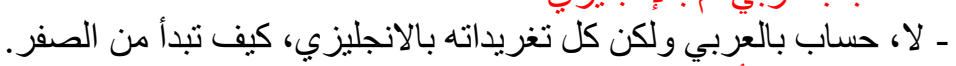

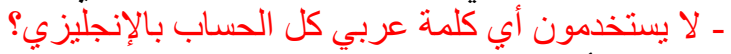
- بعض الأحيان حين يشرحون للناس و الحساب فكرته كيف يبسط اللغة الإنجليزية للطالب الغير إنجليزي.

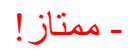

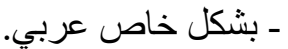

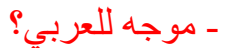

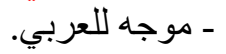

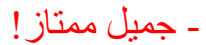

-linking words. - رائع! -

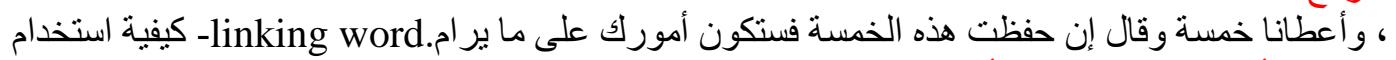

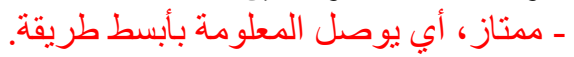

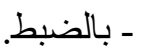

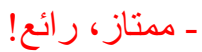
ـ طبعا في ناس يتفاعلون معاه ويشرحون معه ويعطيهم المصادر وبعض الكتب، وبعض الأحيان صور بحيث

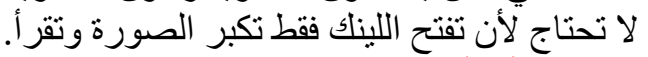

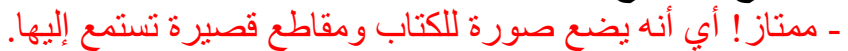

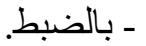

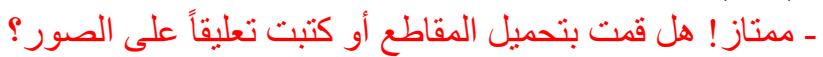

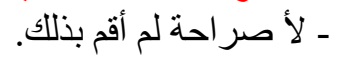

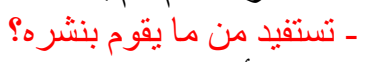

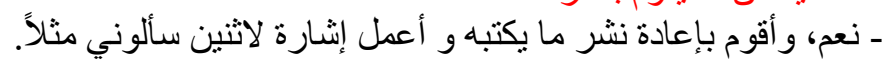

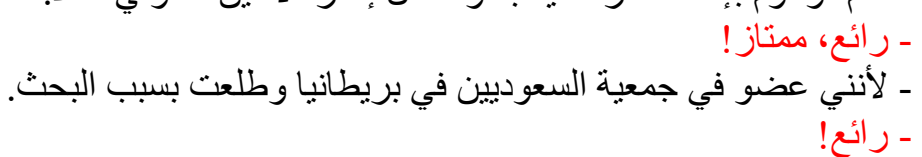

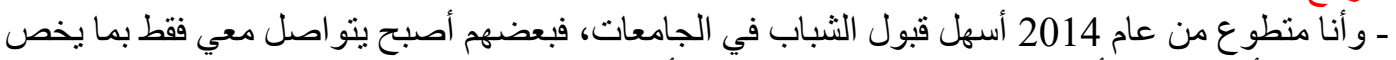

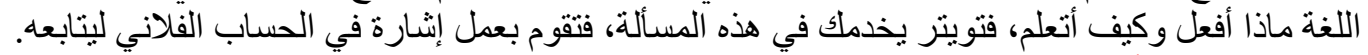

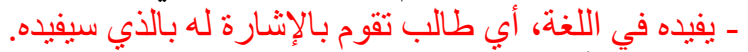

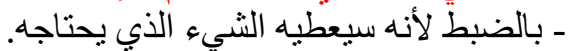

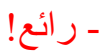
- ويدخل المفضلات لديه ويقر أ كل شي قديم أو جديد ويتابع كل شيء أو لا بأول.

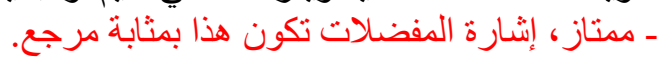

-memo.

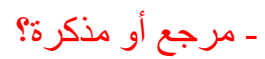

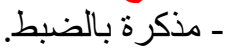
- مدتاز ، رائع! الحساب الذي تثابعه للغة الإنجليزية كم يشكل من 500، 50\% أو 30 \%\%؟

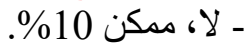
$؟ 10-$ ـ هل كلها موجهة بالعربي أم هنالك درس الإنجليزي بالعربي أو درس الإنجليزي بالإنجليزي هل فهمت قصدي? - من ألإنجليزي للعربي أو من العربي للإنجليزي.

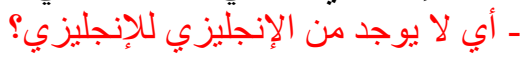
- لا يوجد حساب إنجليزي يشرح من الإنجليزي للإنجليزي؟

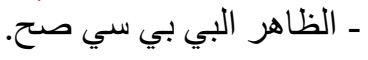




$$
\text { - البي بي سي تعطي نفس الفكرة و القو امبس تعطي؟ }
$$

- نعم، حتى القو اميس لها حسابات على تويتر وينشرون.

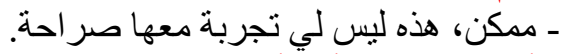

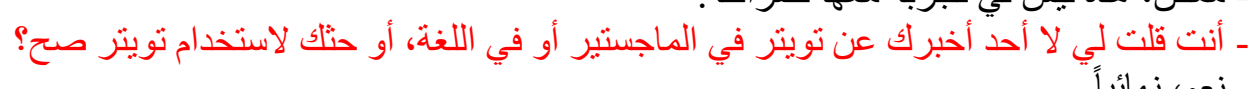

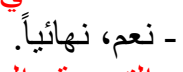
ـ ـ التجربة و الدافع كان مناك؟

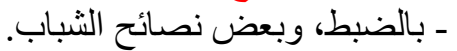

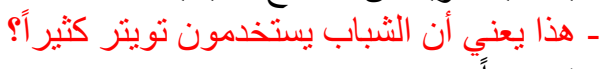

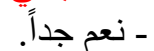

- هل استخدمنه داخل القاعات أم خار جها؟

ـ ـ استخدمه للاردشة ومتابعة الأخبار نعم، أما كاستخدام للغة لأ.

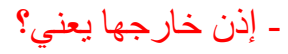

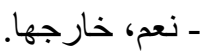

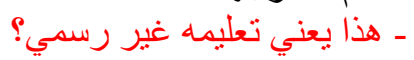

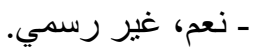

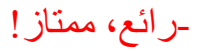

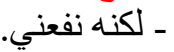

ـ تجربتلك من عام 2014 بدأت صح؟ ماهو الفرق بين استخدامك له من أول أسبوع لتعلم اللغة إلى آخر شهر؟

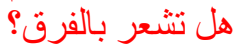

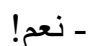
ـ كيف ذللك؟ - معن

ـ أصبحت أنابع حسابات إنجليزية.

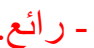
ـ مثنالا البي بي سي للترجمة وبي بي سي الأخبار.

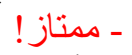

- ـ أصبحت الب القر اعة لدي أسهل لأن (التكر ار يعلم الثطار).

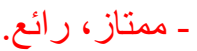
ـ فأصبحت أتابع الحسابات الإنجليزي إنجليزي ليس للغة، إنما لتطوير اللغة.

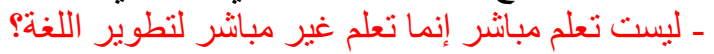

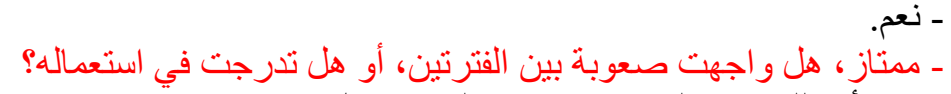
ـ لا، لأن اللغة الانجليزية كانت قوية لانية لدي منذ ال 2007.

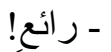

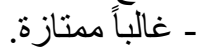

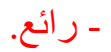

- و الذي يصعب عليا أستعين بمترجم قوقل يحول لي أي كلمة.

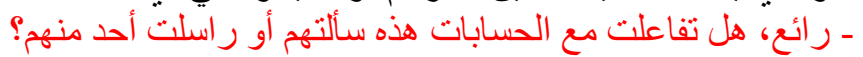

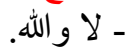

فقط التعلم، اللهم تقوم بالتغريد أو إعادة التغريد؟ باله

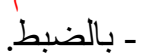
ـ ـ مهتاز ، الحسابات التي تثابعها قلت لي عشر حسابات؟ $\% 10-$

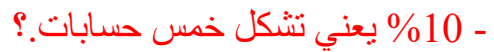

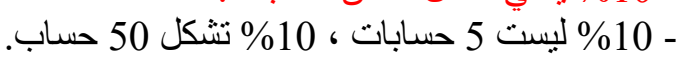
ـ - نعم 50 حساب. - 50 حساب مهتاز جداً.

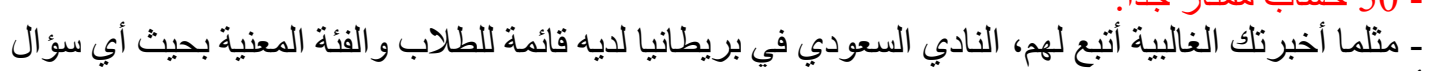
أو استفسار يتم تحويله لهم.

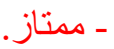




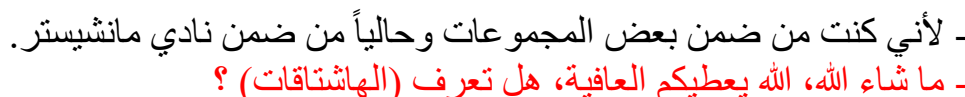

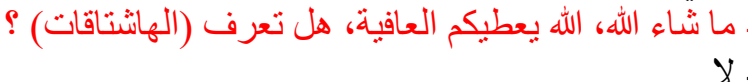

ـ ـتفاعل معها؟ هل هناك هاثتاقات معينة تزور ها باللغة الإنجليزية؟ ـ اللغة الإنجليزية لأول

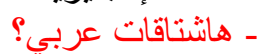

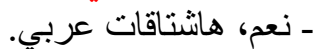

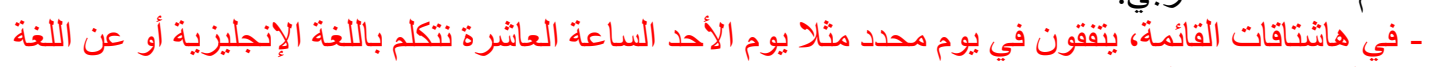

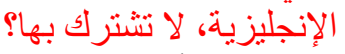

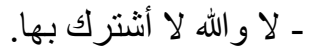

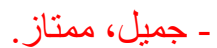

ـ لكن كفكرة ممتازة صر احة، يبدو أن الإعلام ضعيف بها لهذا لم أسمع بها.

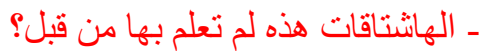
४ - م و الحسابات التي تغرد بها؟

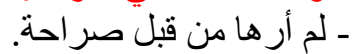

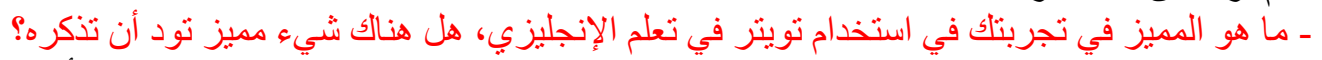

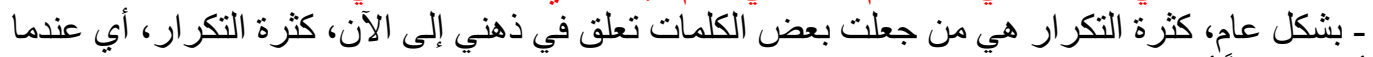
أدخله طبعاً أصبحت مدمن الكرار الآن.

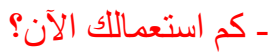

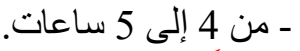

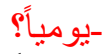

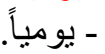
- ما شاء الله. ـ مثلما أخبرتلك بسبب الفراغ، وأنت في الحافلة، في المطعم في انتظار الطلب.

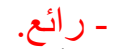
- و وأنا لست من محبين الكرة، لهذا تجدني ليالي أتابع على تويتر.

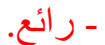
ـ هذا من الأسباب التي جعلتي أستخدم تويتر بكثرة، أي أن التكرار أكثر إفادة في تثبيت بعض الكلمات، وفي

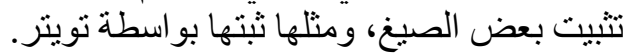

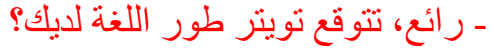

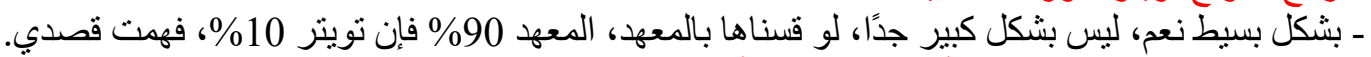

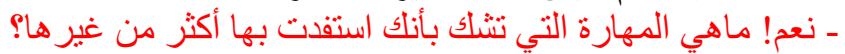

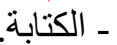

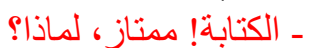

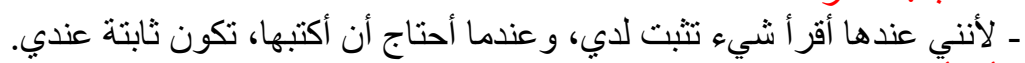

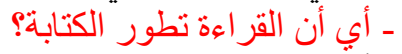

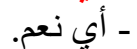
ـ مثتاز ، جميل، تصور كُ عن تويتر بشكل عام هل بيساعد في تعلم اللغة أم لا بياعد؟

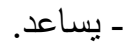

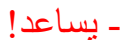

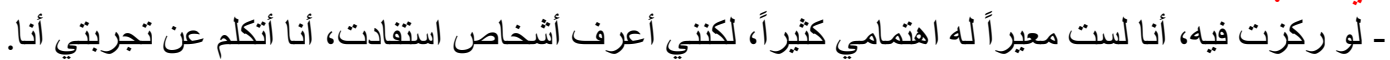

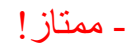

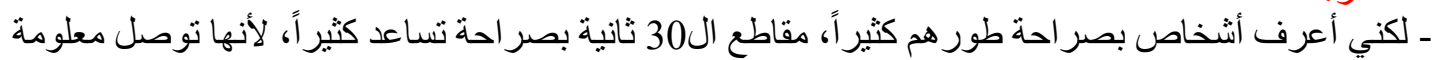

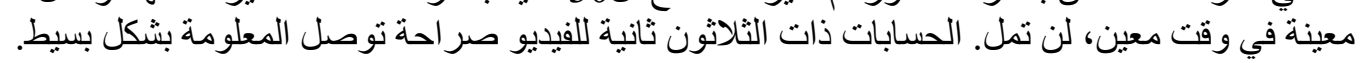

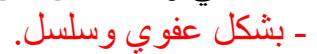
ـ بالضبط، فأي نعم تويتر مفيد جداً جداً في تعلم اللغة الإنجليزية، خصوصاً لنا كمبتعثين نحتاجها أكثر من غيرنا في السعودية. ـ كمثناز ، طبعا أنت بدأت تجربتأك في استخدام تويتز هنا في بريطانيا قبل السعودية؟ ـ لا قبل في السعودية في 2012. 
ـ كنت في السعودية تستخدم الإنجليزي؟ ـ ل ال لا آسف، في بريطانيا كإنجليزي.

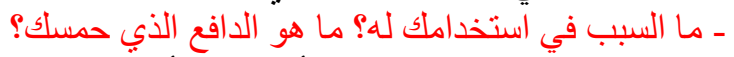

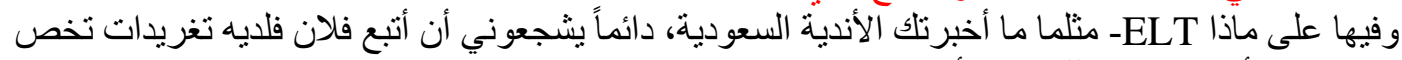

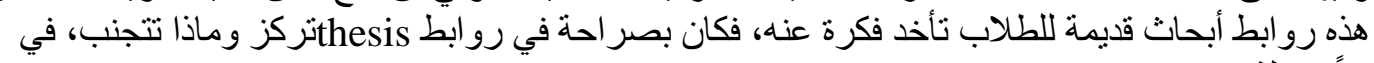

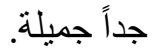

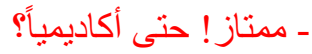

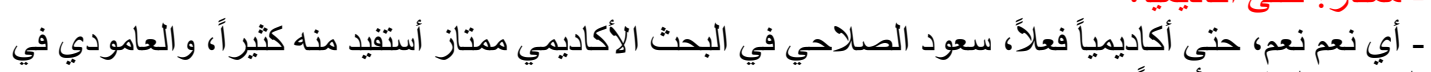
التربية و التطوير أيضاً. - جميل، جمبل جداً، أنا أعبد عليك بعض الأسئلة لكن ليست مشكلة.

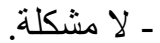

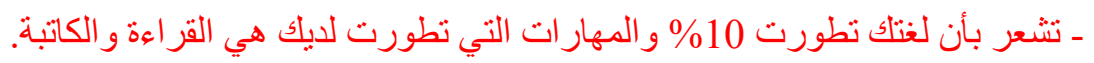

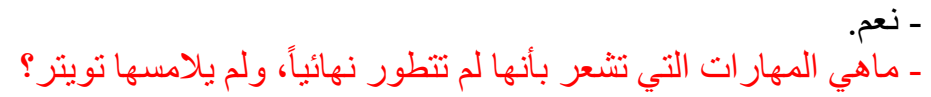

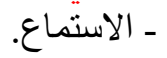

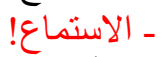

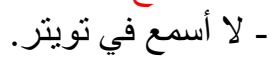

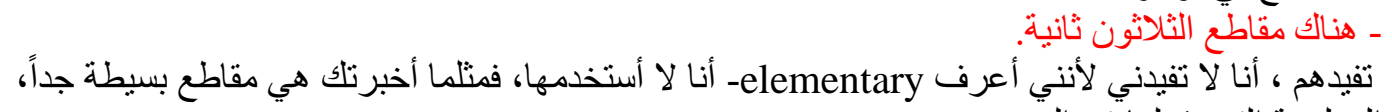

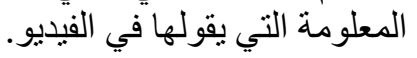

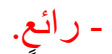
ـ مثناً تثناهد العنوان ثُم تضغط على الفيديو ليصدر الصوت.

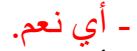
فأمر ع الفيديو و لا أشناهده.Was- أنا لا أضغط لأن المعلومة أعرفها، فمثلا كيف تستخدم - ممتاز، هذه قو اعد أكثر وليست استماع.

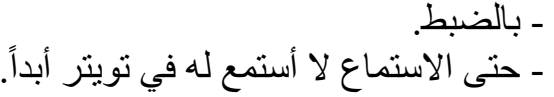

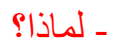
ـ مثلما أخبرتلك، لا يجذبني صر احة، تعودت أن أن أقر أ.

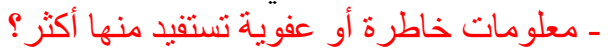

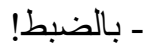

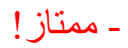
ـ ـ وأحيانا تكون في أماكن عامة و لا نريد تشغيل الفيديو وخاصة إن كان أحدهم يتحدث، فمن العيب أن تشغل

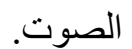

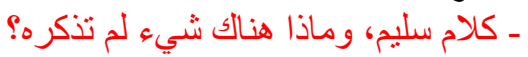

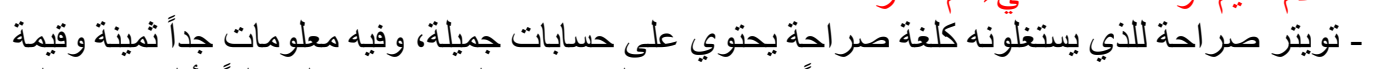

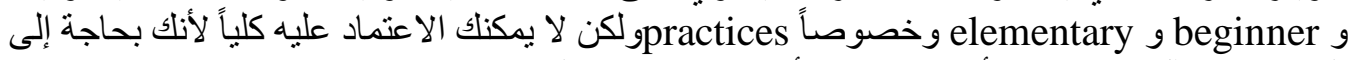

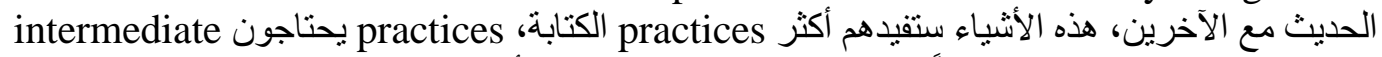

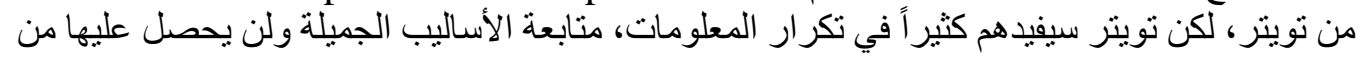

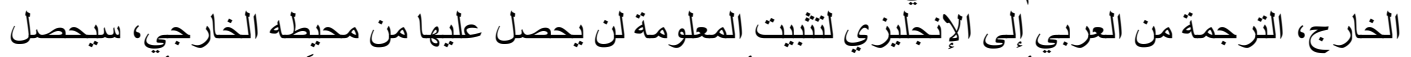

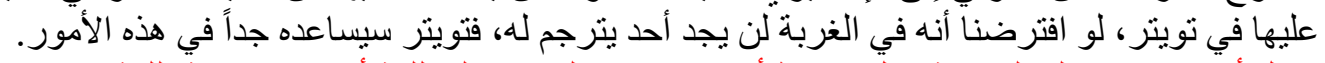

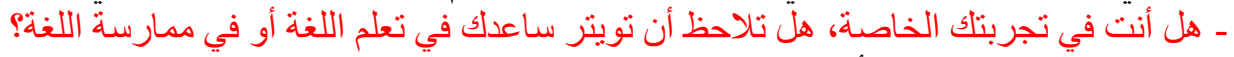
- ساعدني في ممارسة اللغة أكثر. ـ كيف ذللك؟ أنا أمتلك لغة ممتازة منذ 2007 وسجلت في تويتر في 2012 فلم يضف الثيء الكثير. ـ الممارسة تكون على شكل ماذا؟

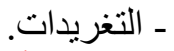
- إنكا تقدم أخبار بالانجليزي فيها نوع من الممارسة ما تتعلم وتطور لغتك.

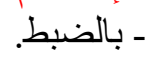

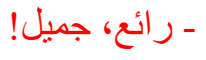


- بعض الأخوان يكتبون بالانجليزي يشاركنا المعلومات بالانجليزي.

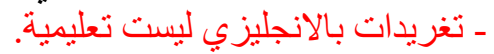
ـ مثنا في مانشستر سوف يحسل يحصل كذا وكذا.. بالانجليزية يكتب فتستفيد أيضاً.

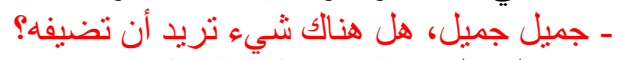

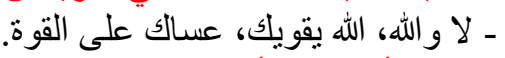

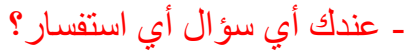

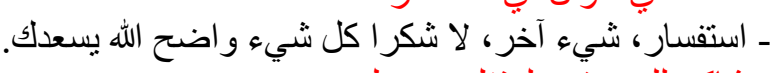

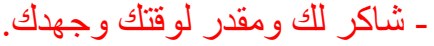

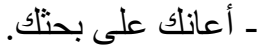

ـ ـ الله بسعدلك، يعطيك العافية

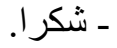




\section{Appendix 4: Consent Form}

\section{Consent Form}

\section{Project name:}

Adult Saudi students' practices and perceptions on utilising Twitter for English language learning in the UK

Researcher: Alharthi Meshari - Master candidate at University of Salford

\section{Purpose of the study:}

This study aims to explore Saudi students' practices and perceptions in the UK on utlising Twitter in English language learning. It will try to investigate they use this social network in English language learning.

I agree to be a participant and interviewed in this study. I am aware that my answers will be used for analysis of this project and they will remain anonymous (My name will be anonymous and not mentioned in the study report).

Name:

Date:

Signature:

To get a copy of the report when it is completed, please email me at: m.alharthi@edu.salford.ac.uk 


\section{Appendix 5: Participants' Characteristics}

These graphs are about participants' characteristics and demographic information:

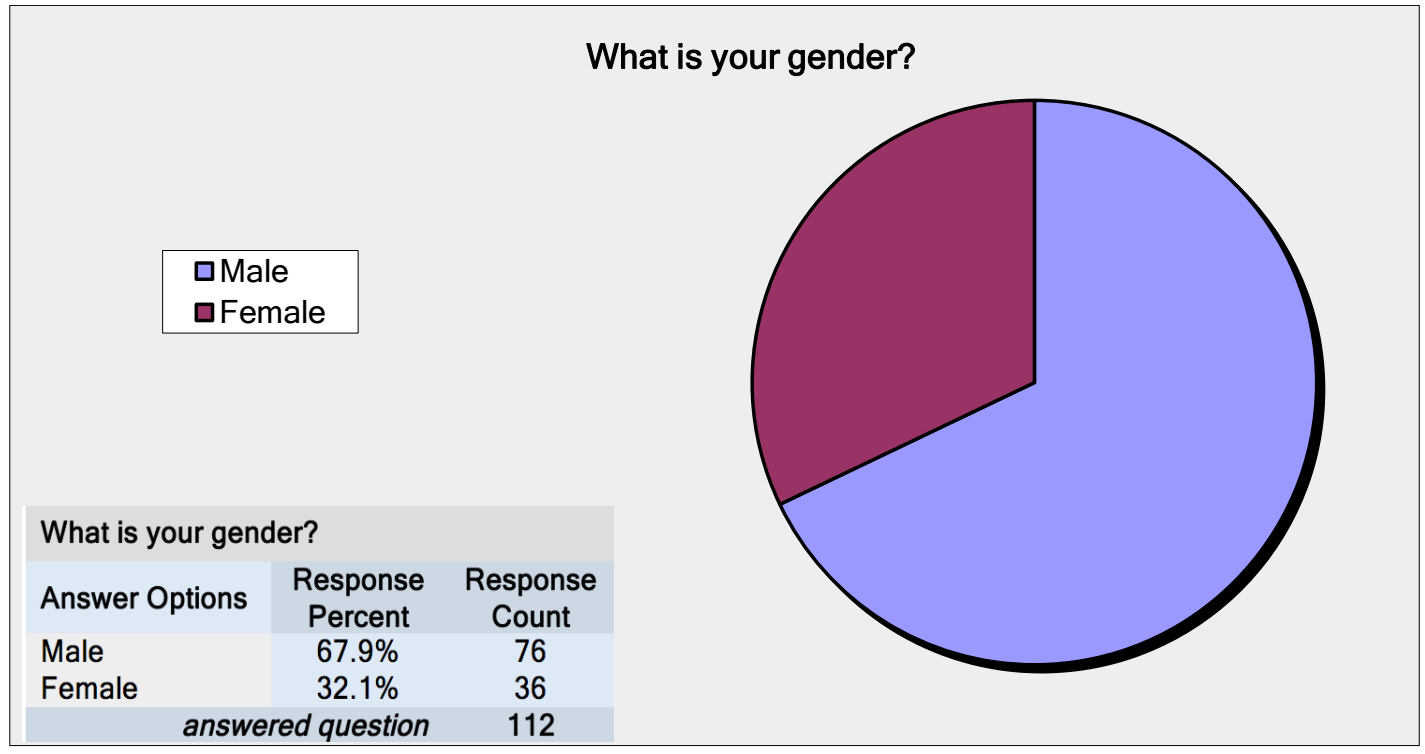

Figure 1

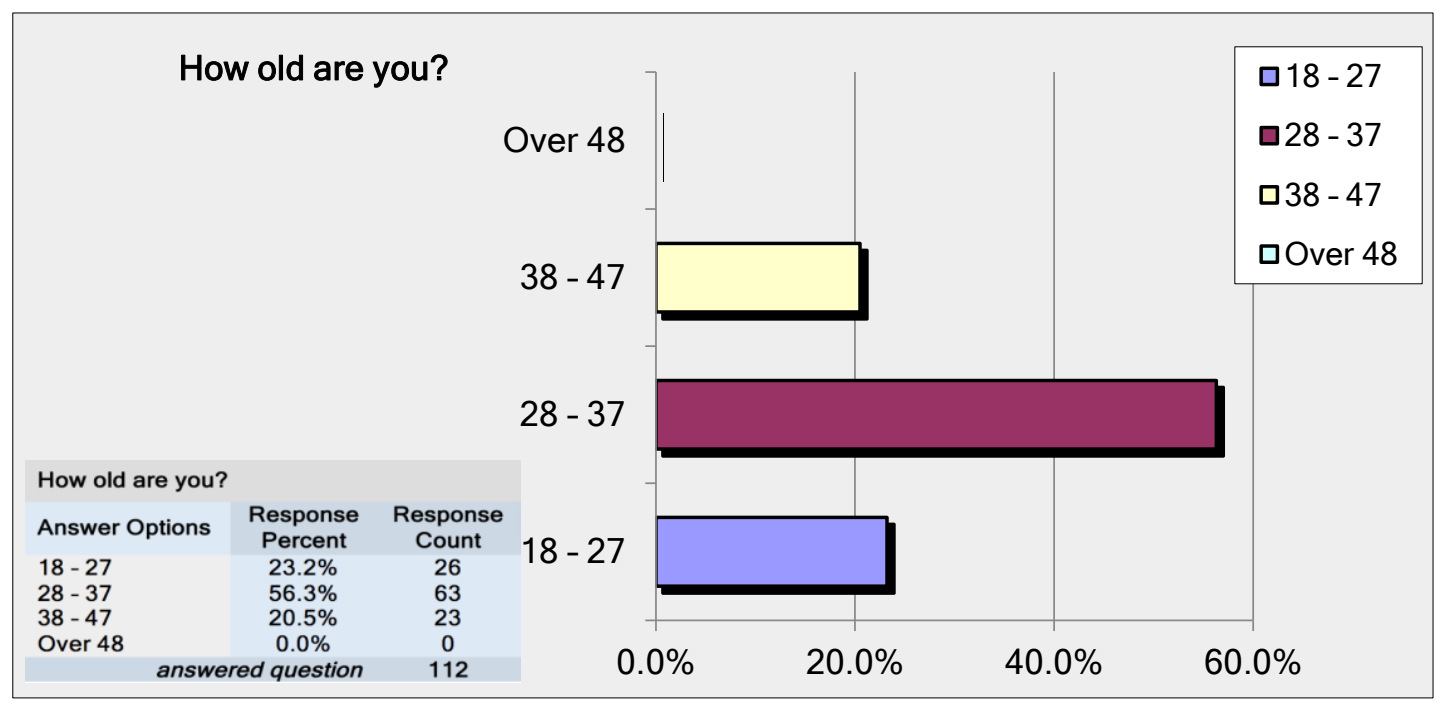

Figure 2 
What are you studying? (You can tick more than one

What are you studying? (You can tick more than one choice)

Answer Options

General and Intensive English

Response Response

English for Academic Purposes (EAP)

Percent

Count

$18.8 \% \quad 21$

Pre-sessional course

$33.0 \%$

$15.2 \%$

English for Business purpose

Others

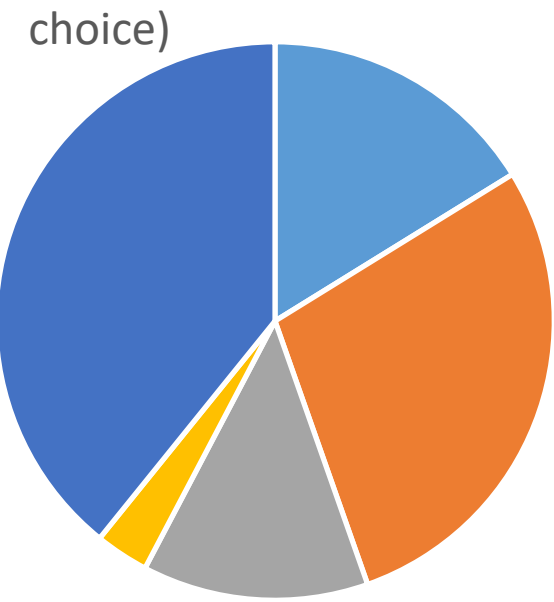

- General and Intensive English

- English for Academic Purposes (EAP)

- Pre-sessional course

English for Business purpose

- Others

Figure 3

Where are you studying?

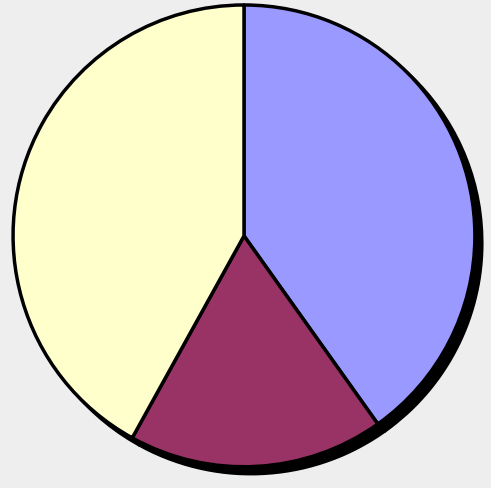

Where are you studying?

Answer Options

Response Response

University language Centre Private school of English Others

Figure 4 


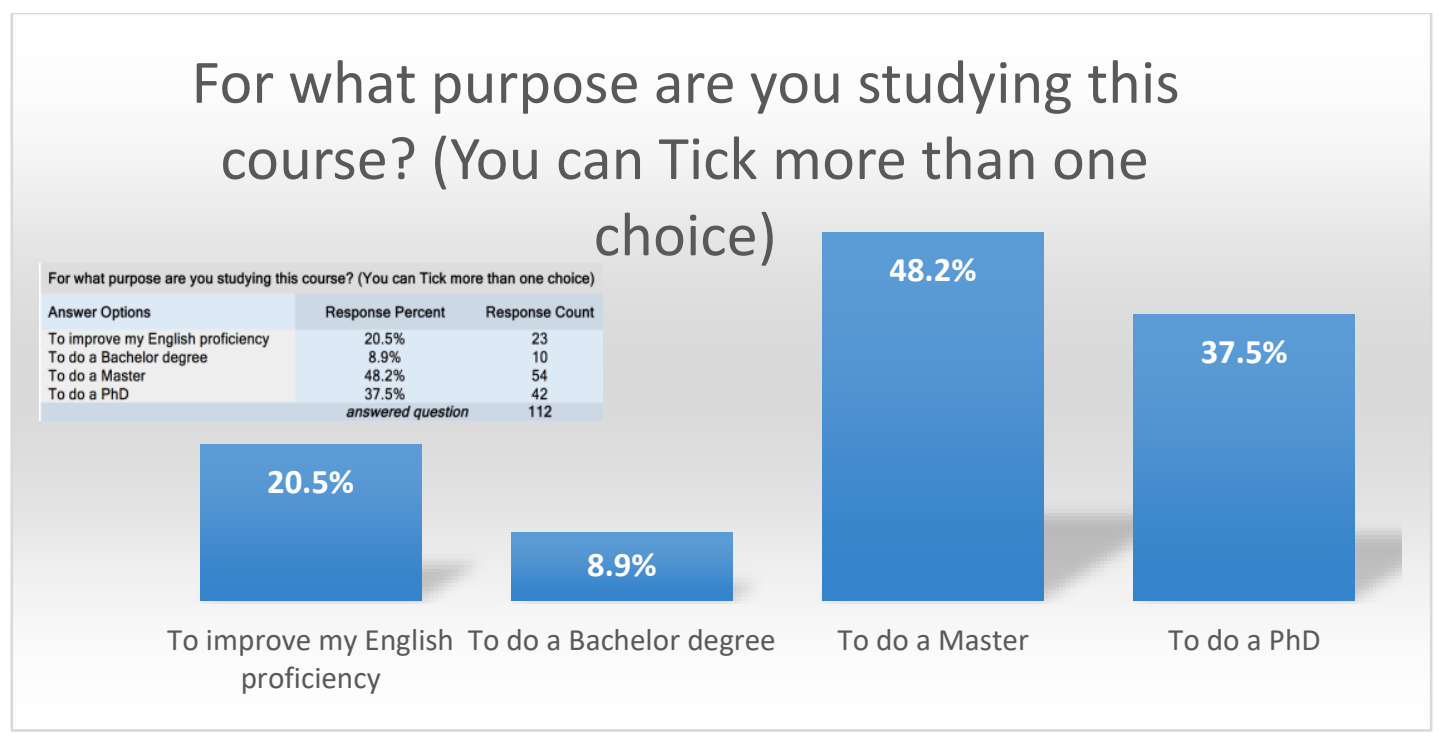

Figure 5 


\section{Appendix 6: Questionnaire}

1.

Thank you for agreeing to take part in this important survey which aims at gathering information about your practices and perceptions on utilizing Twitter for English language learning. I will be gaining your experiences in order to find out how do you use Twitter in English language learning and to what extent do you believe that your language learning is enhanced by the use of Twitter. This survey is specifically directed at Saudis who live in the UK.

The survey should only take about 6 minutes to complete. Be assured that all information will be treated as confidential and you will not be personally named in any reported findings.

Please click 'I agree to participate' to begin.

* 1. Agreement of participation

I agree to participate in this questionnaire 


\section{Use of Twitter}

* 2. How often do you use Twitter in a typical week ? (Tick only one choice)

Once a week or less

2 or 4 times a week

5 times a week or more

* 3. How long have you been using Twitter? (Tick one choice)

about 6 months

about one year

about 2 years

about 3 years

4 years and more

* 4. When using Twitter, which devices do you use? (You can Tick more than one choice)

Mobile devices (Smartphones, tablets, ....)

Desktop

Laptop

* 5. What other social networks do you use?(You can Tick more than one choice)

Facebook

Youtube

Blogs

Instgram

Snapchat

Others 
3. The use of Twitter for English language learning

*6. How often do you use Twitter in English language ( Including; eitherconsciously practising or using it unconsciously to pick up English ) ? (Tick one choice)

5 times a week or more

2 or 3 times a week

Once a week or less

Never 
4. The use of Twitter for English language learning

* 7. How long have you been using Twitter for the purpose of English language learning? (Tick only one choice)
Less than 1 year
1 year
2 years
3 years
4 years and more

* 8. When using Twitter outside of your studies, which language do you use? (Tick only one choice)
Arabic
English

Both

* 9. When using Twitter to improve and practice your English, which language do you use? (Tick only one choice)
Arabic
English
Both

* 10. When doing activities to improve and practice your English such as following accounts, reading tweets and tweeting in hashtags, which language do you use? (Tick only one choice)
Afabic
English
Both

* 11. When using Twitter for English language learning, where do you use it? (Tick only one choice)

Inside the classroom

Outside the classroom

Both 


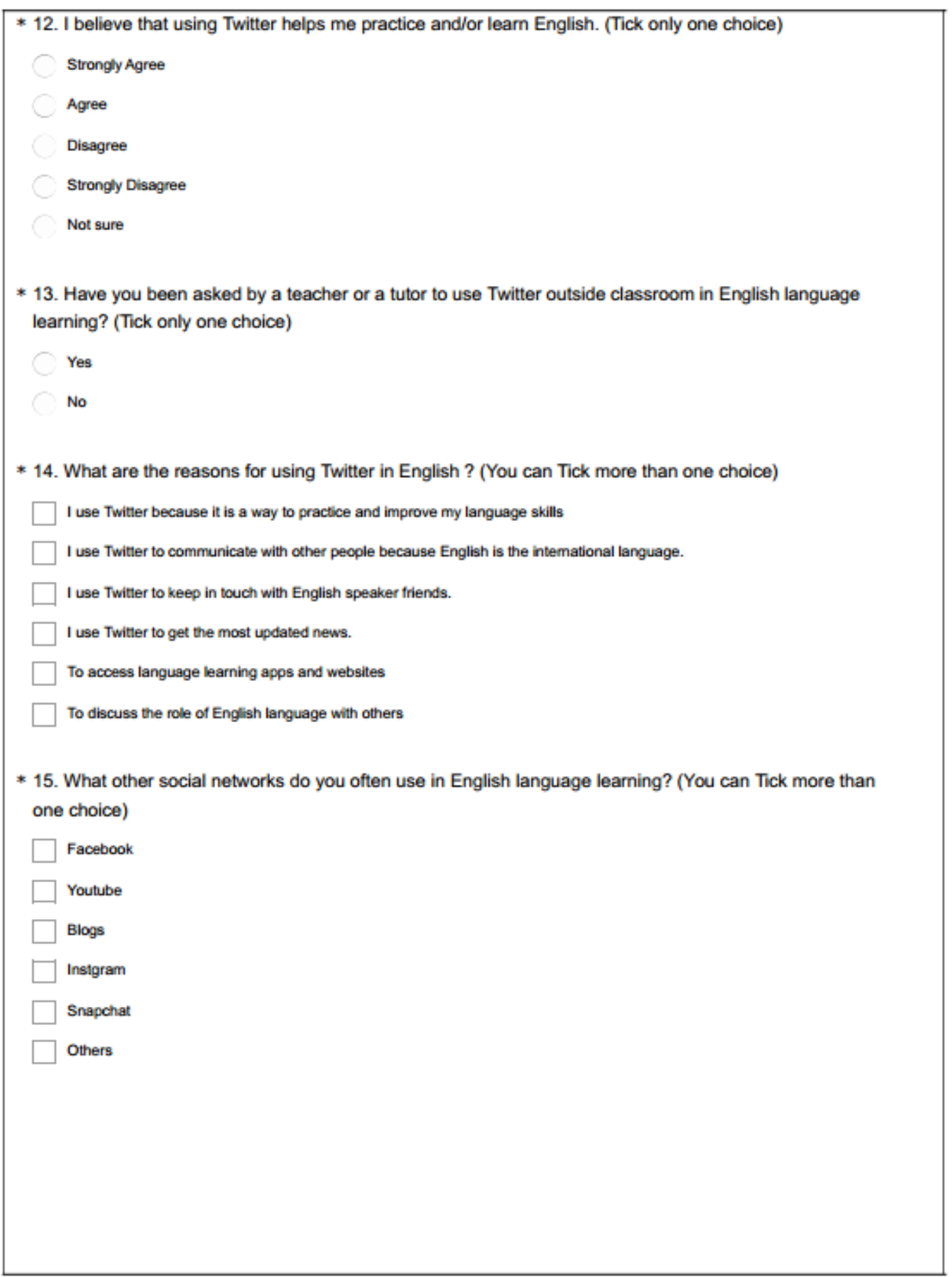




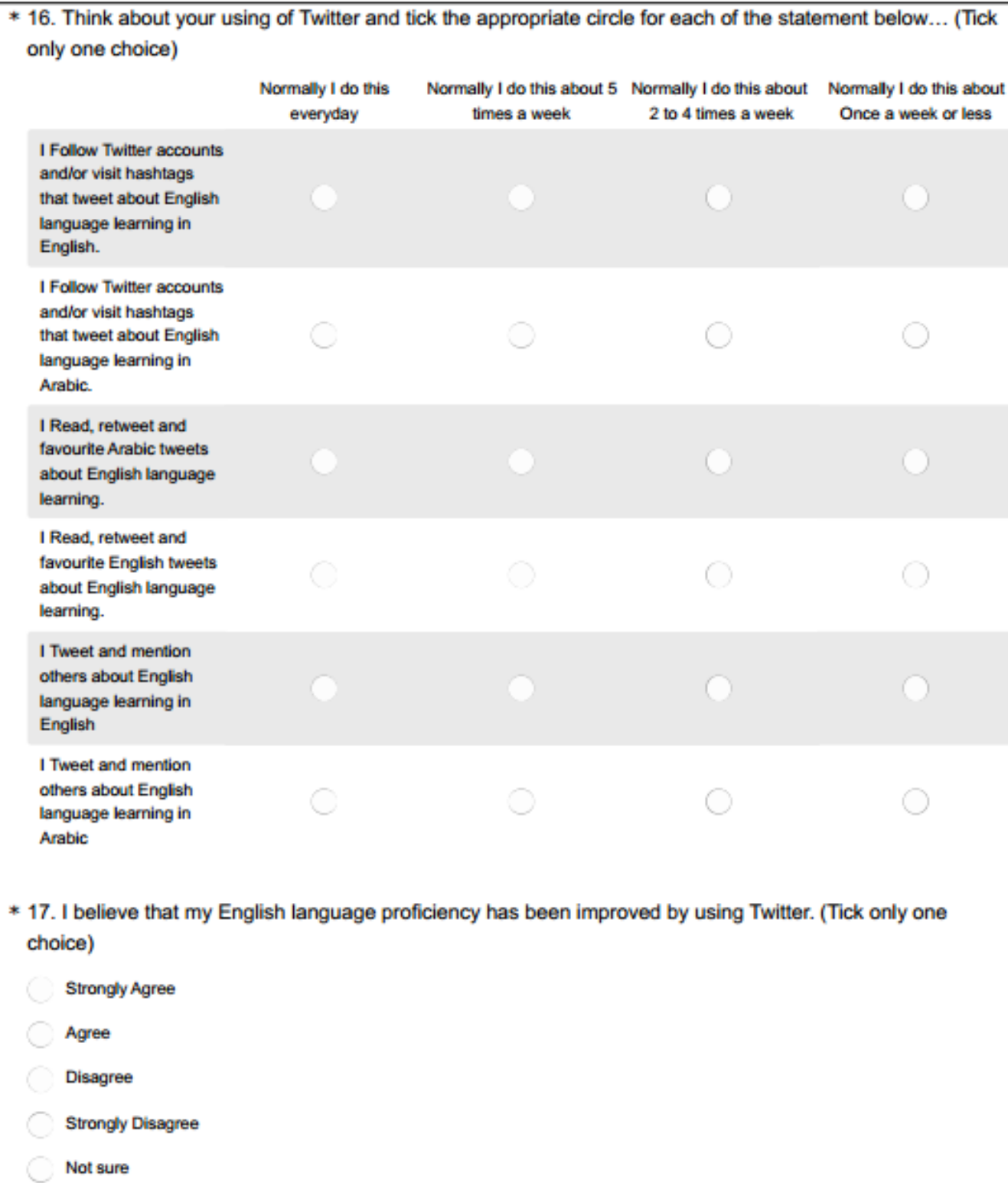

* 17. I believe that my English language proficiency has been improved by using Twitter. (Tick only one choice)
Strongly Agree
Agree
Disagree
Strongly Disagree
Not sure 
5. General Information

* 18. How old are you?

$18-27$

$28-37$

$38-47$

Over 48

* 19. What is your gender?

Male

Female

* 20. What are you studying? (You can tick more than one choice)

General and Intensive English

English for Academic Purposes (EAP)

Pre-sessional course

English for Business purpose

Others

*21. Where are you studying?

University language Centre

Private school of English

Others

* 22. For what purpose are you studying this course? (You can Tick more than one choice)

$\square$ To improve my English proficiency

$\square$ To do a Bachelor degree

To do a Master

To do a PhD 


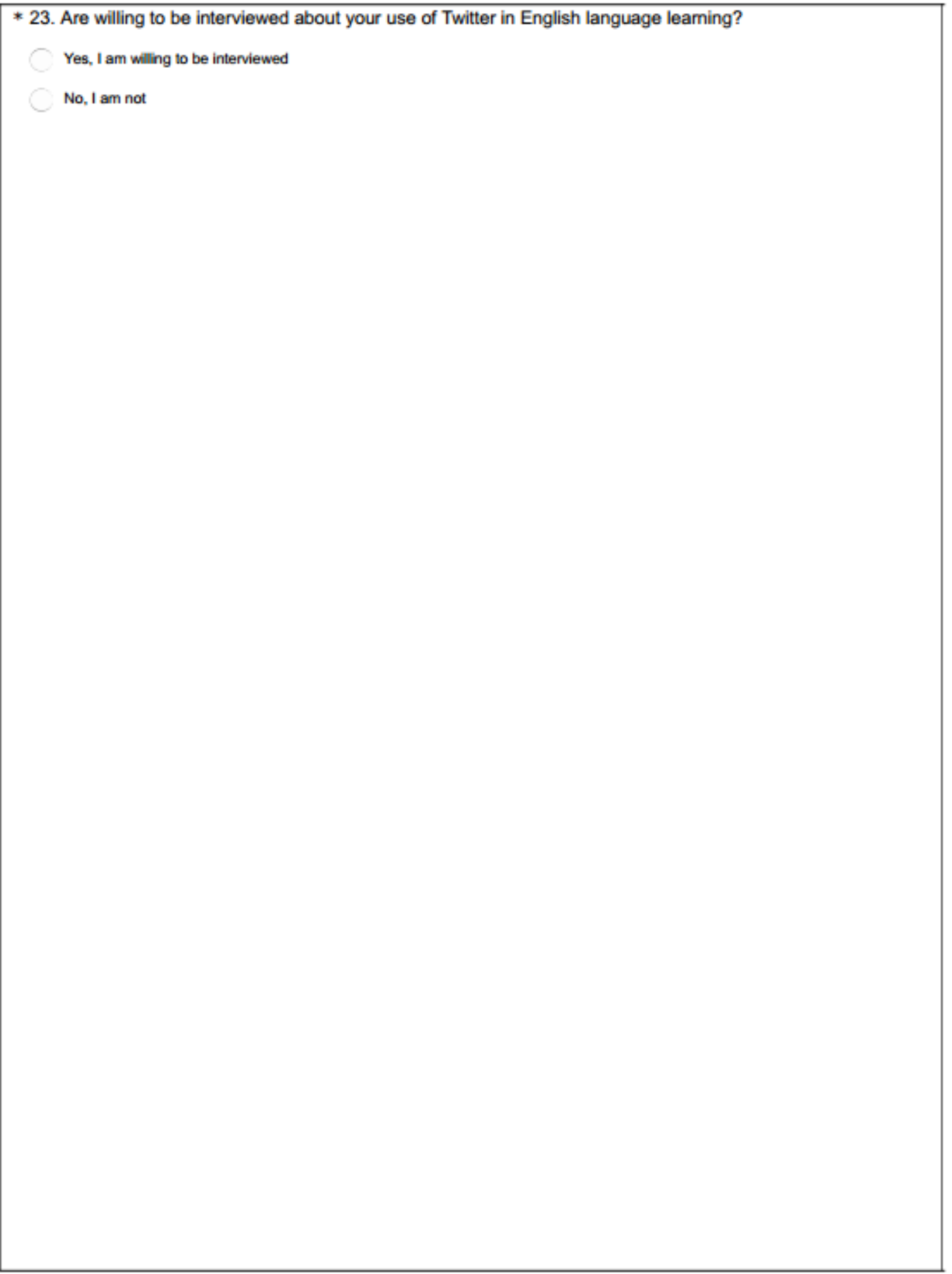




\section{Contact details}

* 24. Please write down your name, phone number and email if you are willing to be interviewed. Note that all information will be treated as confidential and you will not be personally named in any reported findings.

Name

Email Address

Phone Number "Optional" 
7. The end of the questionnaire

Thank you for participation and for finding time to complete this questionnaire! 


\section{Appendix 7: Interview Questions}

\section{Introduction:}

- Hello!

- How are you?

- Offering some drinks.

- An overview about the interview

\section{Easy opening questions:}

- How long have you been in the UK?

- What are you studying?

- Where are you from?

\section{Core part of the interview:}

- Do you believe that using Twitter helps in English language learning?

- Why or why not?

- How?

- Do think that your English is better after using Twitter?

- Describe how you use twitter?

- Tell me about your experiences in using Twitter in English language learning?

- Have you faced any difficulties?

- What are the difficulties?

- Tell me about your first experience?

- How is it different now?

- Tell me about Twitter account that you follow?

- How are they helpful? Why/not?

- What are the hashtags that you visit, read and tweet in?

- How do they facilitate your English language learning?

- Do you use Twitter to practice English or to learn English?

\section{Winding down:}

- Do you want do add anything?

- Do you have any questions?

- Thanking participant and farewell. 


\title{
Appendix 8: Ethical Approval
}

\author{
University of Ethical Approval Panel for Taught Programmes

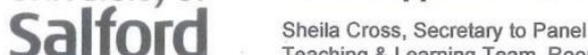 \\ Teaching \& Learning Team, Room 121, Lady Hale Building \\ Email: CBL-tanditeam@salford.ac.uk I Tel: 01612952099
}

Application Form for Ethical Approval for Taught Programmes

Instructions for use

Most applications for ethical approval will be able to be granted by the supervisor. Students should complete Part A and forward to their supervisor, who will complete Part B. In some cases, if the supervisor believes the proposal should be sent to the college ethical approval panel for guidance and clearance, Part $\mathrm{C}$ should be completed and sent to the email address provided above. Supervisors should send Parts A, B and C to the panel in these cases.

PART A To be completed by the student and signed off by the supervisor to confirm that they have seen the proposal and are in agreement that it is sound but requires ethical approval. This form concentrates on the reason for the project and the methodology to be used, with particular emphasis on the ethical issues involved.

PART B To be completed by the supervisor by ticking the relevant box. If ethical approval is granted the supervisor should give this form to the student to include in their dissertation, along with Part A. Nothing further needs to be done with the application at this point.

However, if ethical approval is rejected by the supervisor they should consult with the student as to the required changes and complete Part c.

PART C To be completed by the supervisor if ethical approval is required, with an indication of the key issues and areas for approval, and forwarded, together with Parts $A$ and $B$ to the College Teaching and Learning Office above. The application will then go through the formal ethical approval process. 


\section{University of Ethical Approval Panel for Taught Programmes

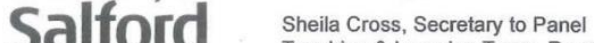 \\ Teaching \& Learning Team, Room 121, Lady Hale Building \\ MANCHESTER_Email:CBL-tandlteam@salford.ac.uk I Tel: 01612952099}

PART A - Application Form for Ethical Approval for Taught Programmes

For completion by Student

Please consult the guide provided and your supervisor when completing this form.

\begin{tabular}{l} 
Student's Full Name: \\
Alharthi Meshari Muidh \\
\hline Supervisor's Name and Signature: \\
Huw Jarvis \\
\hline Title of Research and Project Focus: \\
Saudi adult students' perceptions and practices on Utilizing Twitter for English language \\
learning in Manchester. \\
\hline Project Aims and Objectives: \\
This study aims to explore Saudi students' perspectives in Manchester on utlising \\
Twitter in English language learning. It will try to investigate their practices and \\
perceptions in using this social network in English language learning. \\
\hline Research Methodology: \\
Mixed methods \\
\hline Organisational Agreement (if applicable): \\
\hline Not needed \\
\hline Approaching Individuals (if applicable): \\
\hline $\begin{array}{l}\text { Participants will be approached via Twitter by tweeting the link for the questionnaire and } \\
\text { mention Twitter account of Saudi Students Club in Manchester (@ksamcr). }\end{array}$ \\
\hline How will you ensure 'informed consent' is gained from anyone involved in the research? \\
\hline $\begin{array}{l}\text { The informed consent will be gained by putting it in the first step for the questionnaire link } \\
\text { before starting it. }\end{array}$ \\
\hline How will you approach data protection issues during your research? \\
All information will be stored carefully in my personal usB. Once the research is completed, \\
all of information deleted. \\
\hline $\begin{array}{l}\text { Does this project require that the researcher applies for a Disclosure Barring Service (DBS) } \\
\text { check? }\end{array}$ \\
\hline
\end{tabular}




\begin{tabular}{l} 
Wo \\
What other ethical issues should you consider when conducting this research and how will \\
There are no other ethical issues that should be considered when conducting this research. \\
Does your project require you to conform to any additional professional code of ethics such \\
as provided by the British Society of Criminology or British Psychology Society or Law \\
Society or any other similar professional body? \\
No \\
\hline If you have answered YES above please cite the code and either include it as an appendix \\
to this application or provide details below about where it can be consulted electronically. \\
\hline \\
\hline
\end{tabular}


University of Ethical Approval Panel for Taught Programmes

Salford Sheila cross, secretary to Panet

Teaching \& Learning Team, Room 121, Lady Hale Building

Email: CBL-tandlteam@salford.ac.uk I Tel: 01612952099

PART B - Application Form for Ethical Approval for Taught Programmes

To be completed by Supervisor

\begin{tabular}{l} 
Application Reference Number: (Office Use only) \\
\hline Student's Full Name: \\
Alharthi Meshari Muidh \\
Title of Research and Project Focus: \\
Saudi adult students' perceptions and practices on Utilizing Twitter for English language \\
learning in Manchester. \\
Supervisor's Name and Signature: \\
Huw Jarvis
\end{tabular}

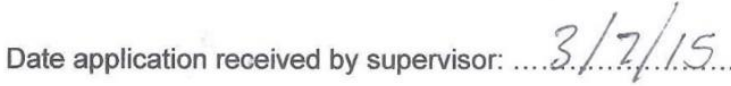

Please tick appropriate box below by double-clicking on the box:

Ethical Approval Granted

(Please send copy of form to student to include in their dissertation).

$\square \quad$ Ethical Approval Rejected

(If rejected please consult with student as to the required changes).

$\square \quad$ Ethical Approval Referred

(If supervisor has queries or concerns in relation to this application please fill in Part $\mathrm{C}$ below and forward to the College Ethical Approval for Taught Panel). 
Appendix 9: Research Procedures

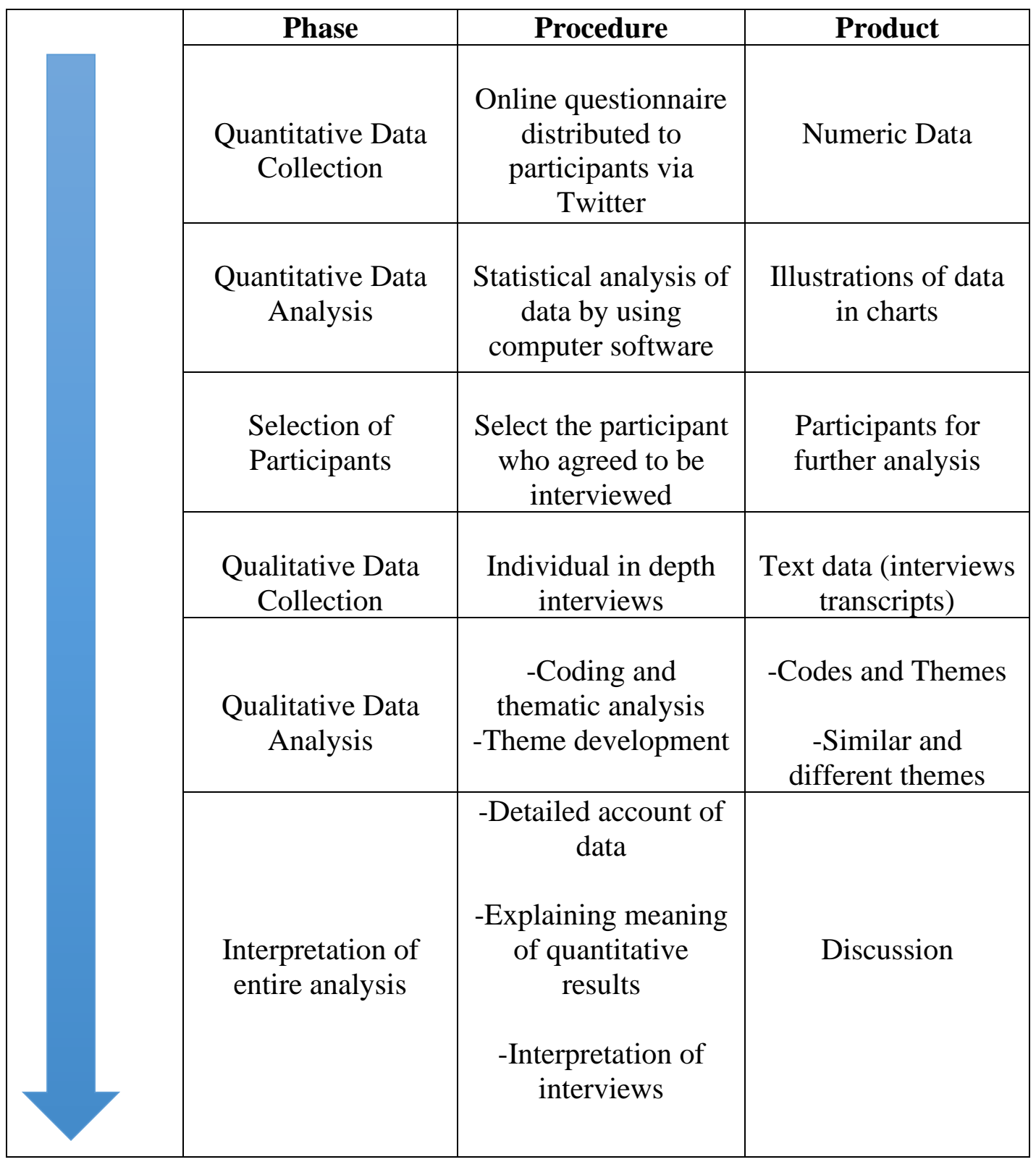

